\title{
Thiomaltol-Based Organometallic Complexes with 1-Methylimidazole as Leaving Group: Synthesis, Stability, and Biological Behavior
}

\author{
Carmen M. Hackl, ${ }^{[a]}$ Maria S. Legina, ${ }^{[a]}$ Verena Pichler, ${ }^{[a]}$ Melanie Schmidlehner, ${ }^{[a]}$ \\ Alexander Roller, ${ }^{[\mathrm{a}]}$ Orsolya Dömötör, ${ }^{[\mathrm{b}, \mathrm{c}]}$ Eva A. Enyedy, ${ }^{[\mathrm{b}]}$ Michael A. Jakupec, ${ }^{\left[{ }^{[a}, \mathrm{d}\right]}$ \\ Wolfgang Kandioller, ${ }^{*[a, d]}$ and Bernhard K. Keppler ${ }^{[a, d]}$
}

\begin{abstract}
Thiomaltol, a potential $S, O$-coordinating molecule, has been utilized for the complexation of four different organometallic fragments, yielding the desired $\mathrm{Ru}^{\prime \prime}, \mathrm{Os}^{\prime \prime}, \mathrm{Rh}^{\text {III, }}$ and IrII complexes having a "piano-stool" configuration. In addition to the synthesis of these compounds with a chlorido leaving group, the analogous 1-methylimidazole derivatives have been prepared, giving rise to thiomaltol-based organometallics with enhanced stability under physiological conditions. The organometallic compounds have been characterized by NMR spectroscopy, elemental analysis, and X-ray dif-
\end{abstract}

fraction analysis. Their behavior in aqueous solution and their interactions with certain amino acids have been studied by ESI mass spectrometry. Their pH-dependent stability has been investigated by ${ }^{1} \mathrm{H}$ NMR in aqueous solution, and their cytotoxicity against three different cancer cell lines has been investigated. Furthermore, their capacity as topoisomerase Il $\alpha$ inhibitors as well as their effect on the cell cycle distribution and reactive oxygen species (ROS) generation have been elucidated.

\section{Introduction}

In recent years, the development of ruthenium-containing compounds has expanded the spectrum of potential anticancer drugs. Considerable impetus has arisen due to the occurrence of a variety of resistances to treatment of different cancer types with commonly applied platinum-based singleagent or combination chemotherapy strategies. ${ }^{[1]}$ One promising drug candidate featuring a ruthenium core is IT-139 (Figure 1); it was thoroughly studied in a phase I clinical trial, in which it demonstrated activity against different tumor types. It was shown that this Ru'll-based drug could be applied in the treatment of non-pancreatic gastrointestinal neuroendocrine tumors, where it influences the GRP78 pathway. GRP78,

[a] C. M. Hackl, M. S. Legina, Dr. V. Pichler, Dr. M. Schmidlehner, A. Roller, Dr. M. A. Jakupec, Dr. W. Kandioller, Prof. Dr. Dr. B. K. Keppler Institute of Inorganic Chemistry, University of Vienna Waehringer Str. 42, 1090 Vienna (Austria) E-mail:wolfgang.kandioller@univie.ac.at

[b] Dr. O. Dömötör, Dr. E. A. Enyedy

Department of Inorganic and Analytical Chemistry University of Szeged, Dóm tér 7, 6720 Szeged (Hungary)

[c] Dr. O. Dömötör

MTA-SZTE Bioinorganic Chemistry Research Group University of Szeged, Dóm tér 7, 6720 Szeged (Hungary)

[d] Dr. M. A. Jakupec, Dr. W. Kandioller, Prof. Dr. Dr. B. K. Keppler Research Platform "Translational Cancer Therapy Research" University of Vienna, Waehringer Str. 42, 1090 Vienna (Austria)

$\square$ Supporting information and the ORCID number(s) for the author(s) of this iD article are available under http://dx.doi.org/10.1002/chem.201603206. a regulator of endoplasmic reticulum stress response, has been found to be significantly upregulated in cancer cells and is accredited with a high impact on tumor cell survival and resistance. ${ }^{[2]}$ Furthermore, evidence for synergy of IT-139 was obtained when it was tested in combination with approved anticancer drugs, such as sorafenib. ${ }^{[3]}$ NAMI-A, as another representative of ruthenium(III) anticancer compounds, showed a divergent activity profile compared to IT-139, despite its structural similarities. Even though this drug demonstrated selective activity in metastatic cells and antiangiogenic activity, ${ }_{1}^{[4,5]}$ clinical trials were discontinued due to poor clinical responses and the absence of a distinctly assignable target. ${ }^{[6]}$ Besides ruthenium(III) compounds, the development of organometallic complexes that contain the metal in its reduced, active form, stabilized by the coordination of an arene ligand to the metal center, has emerged in the field of anticancer drug research. ${ }^{[7]}$ Two representatives of this group of ruthenium(II) organometallic compounds are RAPTA-C and RM175, which have been extensively studied in the course of various preclinical investigations. $^{[7-9]}$

Ruthenium(II) half-sandwich complexes provide a promising approach for the development of anticancer metallodrugs with different modes of action. The impact of ligand variation on the most important characteristics of these compounds has been an active field of research and, through a series of studies, it was demonstrated that the nature of the donor atoms has a considerable impact on the in vitro activity. ${ }^{[10]}$ Low anticancer activities could be explained by insufficient complex stability due to replacement of the active ligand by biomole- 


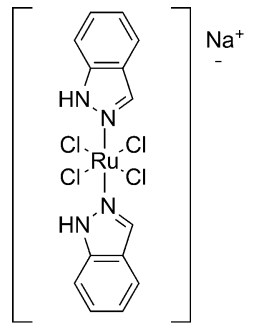

A

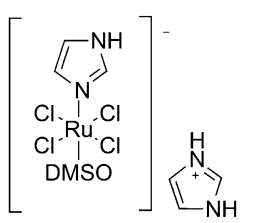

B
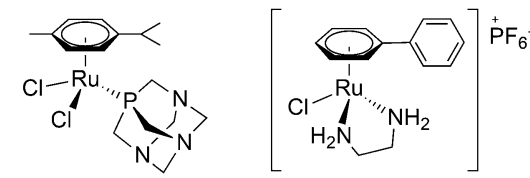

C
D

Figure 1. Important representatives of ruthenium-containing compounds as anticancer agents. From left to right: A) IT-139 (NKP-1339), B) NAMI-A, C) RAPTAC, and D) RM175.

cules, which are omnipresent once the drug has been administered. A thorough investigation and comparison of maltol-derived ruthenium(II) complexes by NMR and ESI-MS supported the assumption that the replacement of an O,O-donor set by an $\mathrm{S}, \mathrm{O}$-donating moiety could increase both aqueous stability and cytotoxic activity, resulting in $\mathrm{IC}_{50}$ values in the low $\mu \mathrm{M}$ range. ${ }^{[11,12]}$ The stronger bond between the metal center and the ligand can be attributed to the softer character of the sulfur atom in comparison to oxygen, which should result in an increased complex stability since ligand-exchange reactions and subsequent inactivation are impeded. ${ }^{[13]}$ As illustrated previously, co-incubation of imidazole with the organoruthenium(II) maltolato complex greatly increased the stability of the complex due to a decelerated aquation process. ${ }^{[12]}$ Since this ligand exchange by a water molecule is thought to be directly related to the activity of a compound, a delayed activation is desired in order to allow for accumulation of the intact drug and subsequent interaction with the cellular target. In this work, we demonstrate that coordination of 1-methylimidazole (Melm) stabilizes the complexes under alkaline conditions, while at the same time offering an interesting approach towards complex activation at the slightly acidic $\mathrm{pH}$ values present in tumor tissues. ${ }^{[14,15]}$ In addition, we have investigated the impacts of metal center and leaving group variation on the physicochemical and biological properties. Preliminary studies have been conducted concerning possible cellular targets, and possible modes of action have been elucidated by investigation of topoisomerase $\| \alpha$ inhibition, reactive oxygen species (ROS) production, and cell cycle analysis.

\section{Results and Discussion}

The introduction of an imidazole moiety in place of a chlorido ligand should increase the stability of complexes in the presence of biomolecules, as well as their solubility, depending on the counter ion of the resulting charged organometallic. Commercially available maltol was used as starting point for this synthetic pathway and was converted to its thionated analogue by reaction with Lawesson's reagent under inert conditions. Complexation was performed under the established reaction conditions. ${ }^{[16,17]}$ The first approach was the direct conversion of $\mathbf{1} \mathbf{a}-\mathbf{d}$ (Scheme 1 ) by the addition of silver trifluoromethanesulfonate and 1-methylimidazole. However, this at- tempt resulted in the formation of compound mixtures that could not be separated. Therefore, a different strategy was applied, involving [bis(1-methylimidazole) $\mathrm{M}(p$-cym/Cp* $) \mathrm{Cl}] \mathrm{Cl}(p-$ cym $=p$-cymene) precursor complexes. In contrast to the situation with the mono-imidazole analogue, only one product was obtained after treatment with thiomaltol. The four required bis(1-methylimidazole) precursors were synthesized by treatment of the respective dimeric metal compounds [M(p-cym/ $\left.\left.C \mathrm{p}^{*}\right) \mathrm{Cl}_{2}\right]_{2}\left(\mathrm{M}=\mathrm{Ru}^{\prime \prime}, \mathrm{Os} \mathrm{s}^{\prime \prime}, \mathrm{Rh}^{\prime \prime \prime}, \mathrm{Ir}^{\prime \prime \prime}\right)$ with a slight excess of 1-methylimidazole under optimized microwave reaction conditions (Scheme 1). ${ }^{[18]}$ In general, coordination of thiomaltol to organometallic moieties requires strictly inert conditions to avoid the formation of undesired by-products. Therefore, the complexation reactions were performed in distilled methanol by means of Schlenk-line techniques. Thiomaltol was deprotonated by using sodium methoxide in dry methanol. After addition of the respective dimeric metal precursor, the reaction mixture was stirred at room temperature for 1.5-24 h, depending on the metal center present. Extraction with dichloromethane and subsequent filtration allowed the isolation of pure complexes. The desired products were obtained by crystallization from dichloromethane/diethyl ether in low to moderate yields (32$52 \%)$. The isolated complexes were characterized by standard analytical methods, such as ${ }^{1} \mathrm{H}$ and ${ }^{13} \mathrm{C}$ NMR, elemental analysis, ESI-MS measurements, and, where possible, by X-ray diffraction analysis. ${ }^{1} \mathrm{H}$ NMR spectra of both the chlorido series as well as of the complexes with 1-methylimidazole were recorded from solutions in deuterated methanol and showed characteristic signals (see Figures S1-S4). The chlorido compounds showed only two doublets attributable to the aromatic protons of the $\eta^{6}$ - $p$-cymene ligand, although four distinct signals could be expected due to the magnetically inequivalent protons. This effect has also been observed for similar maltolato-based organoruthenium(II) and osmium(II) complexes. ${ }^{[19]}$ Substitution by the more sterically demanding 1-methylimidazole moiety leads to a more complex NMR spectrum, which could be rationalized in terms of hindered inversion at the metal center. ESI-MS studies showed complexes $\mathbf{2} \mathbf{a}-\mathbf{d}$ to be more stable than their chlorido analogues $\mathbf{1} \mathbf{a}-\mathbf{d}$ under the applied conditions. $\mathbf{1} \mathbf{a}-\mathbf{d}$ and $\mathbf{2} \mathbf{c}, \mathbf{d}$ formed only $[M-\mathrm{Cl}]^{+}$or $[M-M e l m]^{+}$fragments, whereas complexes $\mathbf{2} \mathbf{a}, \mathbf{b}$ showed signals attributable to the molecular peak $[M]^{+}$and $[M-M e l m]^{+}$. 


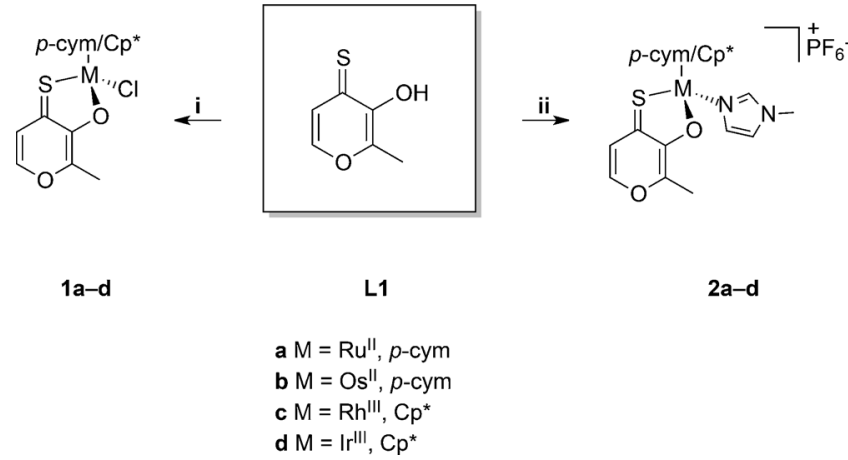

Scheme 1. Overview of synthesized compounds $\mathbf{1} \mathbf{a}-\mathbf{d}$ and $\mathbf{2} \mathbf{a}-\mathbf{d}$. i) $[(p-c y m) /$ $\left.\left(\mathrm{Cp}^{*}\right) \mathrm{MCl}_{2}\right]_{2}, \mathrm{NaOMe}$, methanol abs. ii) $\left[(p-c y m) /\left(\mathrm{Cp}^{*}\right) \mathrm{M}(\mathrm{Melm})_{2} \mathrm{Cl}\right] \mathrm{Cl}, \mathrm{NaOMe}$, methanol abs., $\mathrm{NaPF}_{6}$.

\section{X-ray diffraction analysis}

Single crystals of $\mathbf{1} \mathbf{b}$ and $\mathbf{1} \mathbf{c}$ (Figure 2 ) as well as of $\mathbf{2} \mathbf{a}-\mathbf{d}$ (Figures 3, and Figures S6 and S8 in the Supporting Information) suitable for X-ray diffraction analysis were obtained by precipitation from dichloromethane/ $n$-hexane or dichloromethane/diethyl ether. The crystal structure of $\mathbf{1}$ a has been published previously. ${ }^{[12]}$ All of the complexes adopt the so-called "pianostool" configuration, whereby the stabilizing aromatic ligand forms the seat and the chelating thiomaltolato ligand as well as the respective leaving group (either chlorido or 1-methylimidazole) constitute the chair legs. Upon coordination of thiomaltol to organometallic fragments, a distorted nonplanar fivemembered ring was formed with an O-M-S-C torsion angle ranging from 2.53 to $10.69^{\circ}$. The distortion can be explained by the pronounced difference in bond lengths of the metal ion to the oxygen and sulfur donor atoms [1 a: 2.080 and $2.373 \AA$; $\mathrm{Ru}$ "l maltolato complex: 2.082(3) and 2.108(3) $\AA_{1}{ }^{[4]}$ respectively].
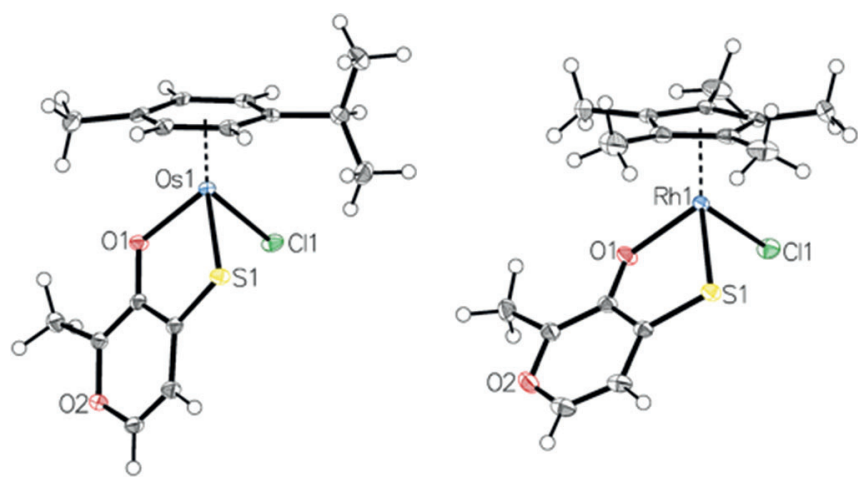

Figure 2. Crystal structures of $\mathbf{1} \mathbf{b}$ and $\mathbf{1}$ c with ellipsoids drawn at the $50 \%$ probability level.

The most salient bond lengths and angles in $\mathbf{1} \mathbf{b}$ and $\mathbf{1} \mathbf{c}$ are summarized in Table 1. Both complexes are representatives of the monoclinic crystal system, with $\mathbf{1} \mathbf{b}$ belonging to the space group $P 2_{1} / c$, whereas $1 \mathrm{c}$ crystallizes in the space group $C 2 / c$. The $\mathrm{M}-\mathrm{Cl}$ distances were found to lie in the same range for both the Os" (1 b) and Rh"I (1 c) complexes [1 b: $2.4357 \AA$; 1 c:
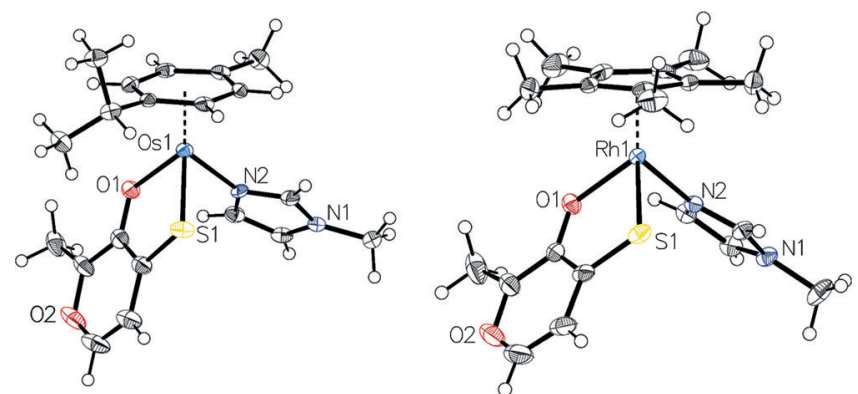

Figure 3. Crystal structures of $\mathbf{2} \mathbf{b}$ and $\mathbf{2}$ c with ellipsoids drawn at the $50 \%$ probability level $\left(\mathrm{PF}_{6}{ }^{-}\right.$counter ion omitted for clarity).

$2.4222 \AA]$, in good agreement with reported data for $1 \mathrm{a}$ $[2.433 \AA]{ }^{[11,12]}$ The $\mathrm{C}-\mathrm{S}$ bond lengths in $\mathbf{1} \mathbf{b}$ and $\mathbf{1} \mathbf{c}$ were found to be slightly longer than in the free ligand $[\mathbf{1 b}$ : $1.7035 \AA, 1 \mathrm{c}$ : $1.7032 \AA, \quad L 1: 1.6770 \AA]^{[2]}$ due to the electron-withdrawing effect of the coordinated metal.

\begin{tabular}{|c|c|c|c|c|}
\hline Compound & $1 \mathrm{~b}$ & $2 b$ & $1 \mathrm{c}$ & $2 c$ \\
\hline$M-S[\AA]$ & 2.3775 & 2.3652 & 2.3637 & 2.3399 \\
\hline $\mathrm{M}-\mathrm{O}[\AA]$ & 2.0864 & 2.0754 & 2.0924 & 2.0731 \\
\hline $\mathrm{M}-\mathrm{Cl} /-\mathrm{N}[\AA]$ & 2.4357 & 2.1011 & 2.4222 & 2.0984 \\
\hline$C=S[\AA]$ & 1.7035 & 1.7082 & 1.7032 & 1.7102 \\
\hline $\mathrm{C}-\mathrm{O}[\AA]$ & 1.3172 & 1.3185 & 1.3091 & 1.3130 \\
\hline$\pi$-plane centroid distance $[\AA]]$ & 1.6619 & 1.6684 & 1.7738 & 1.7692 \\
\hline ring slippage $[\AA]$ & 0.039 & 0.035 & 0.031 & 0.033 \\
\hline $\mathrm{O}-\mathrm{M}-\mathrm{S}-\mathrm{C}\left[{ }^{\circ}\right]$ & 10.69 & 4.92 & 9.95 & 2.53 \\
\hline
\end{tabular}

By comparison of $\mathbf{2} \mathbf{a}-\mathbf{d}$, structural similarity between the Os" and $\mathrm{Ru}^{\mathrm{II}}$ compounds as well as between the $\mathrm{Ir}^{\mathrm{III}}$ and $\mathrm{Rh}^{\mathrm{III}}$ complexes can be observed. Complexes $\mathbf{2} \mathbf{a}$ and $\mathbf{2} \mathbf{b}$ are representatives of the triclinic $P \overline{1}$ space group, whereas compounds $2 \mathrm{c}$ and $\mathbf{2} \mathbf{d}$ belong to the monoclinic space group $P 2_{1} / c$. The metal-azole distance ranges from $2.0981 \AA$ in 2 a to $2.1024 \AA$ in $2 \mathbf{d}$. The measured metal-azole bond lengths are in good agreement with reported data for the corresponding precursor complex $\left[(p-c y m) \mathrm{Ru}(\mathrm{Melm})_{2} \mathrm{Cl}\right] \mathrm{Cl} \quad[2.121(3)$ and $2.131(3) \AA] .^{[20]}$ Selected bond lengths and angles in the chlorido complexes $\mathbf{1 b}$ and $\mathbf{1} \mathrm{c}$ are also listed in Table 1, along with those in their analogues $\mathbf{2} \mathbf{b}$ and $\mathbf{2} \mathbf{c}$ bearing 1-methylimidazole as the leaving group. Overall, substitution of the chlorido ligands by 1methylimidazole resulted in slightly shorter distances between the metal center and the S,O-donor atoms, indicating a higher stability of the attached ligand scaffold. Both pairs of complexes show differences in the $\mathrm{M}$-leaving group bond lengths [1 b: $2.4357 \AA, 2$ b: $2.1011 \AA ; 1$ c: $2.4222 \AA, 2$ c: $2.0984 \AA$ ] due to the different donor atoms. Nevertheless, the $\mathrm{M}-\mathrm{Cl}$ and $\mathrm{M}-\mathrm{N}$ bond lengths in the investigated complexes are in the same range as those in the Ru" complex RM175 published by Sadler and co-workers. ${ }^{[21]}$ An envelope conformation of the five-membered coordination cycle is apparent in both forms of the Os" and $\mathrm{Rh}^{\mathrm{III}}$ complexes, but the torsion angle (O-M-S-C) is less pro- 
nounced in complexes $\mathbf{2} \mathbf{b}$ and $2 \mathbf{c}\left(4.92^{\circ}\right.$ and $2.53^{\circ}$, respectively) compared to their chlorido counterparts $1 \mathrm{~b}$ and $1 \mathrm{c}\left(10.69^{\circ}\right.$ and $9.95^{\circ}$, respectively), which might be attributed to both the increased steric demand of the 1-methylimidazole ligand and the different donor properties. As expected, slightly shorter $\pi$ plane-centroid distances were found for $\eta^{6}$-coordinating moieties compared to the $\eta^{5}$-coordinative bond between the $\mathrm{Cp}^{*}$ ligand and the $\mathrm{Rh}^{\mathrm{III}}$ or $\mathrm{Ir}^{\mathrm{III}}$ metal centers.

\section{Stability investigations by ESI-MS}

The behavior of metal complexes in aqueous media is an important characteristic, since the $\mathrm{M}-\mathrm{Cl}$ bond is prone to hydrolysis. Aquation is believed to be an important step in the mode of action of this compound class, because the comparatively more reactive aqua complex is assumed to interact with biological targets. Therefore, the stability in aqueous solution was investigated for all of the synthesized organometallics bearing

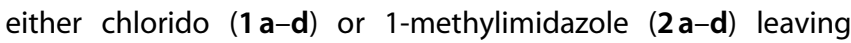
groups. Samples were prepared according to the procedure described in the Experimental Section and examined after 1, 3, 6,24 , and $48 \mathrm{~h}$ of incubation at $37^{\circ} \mathrm{C}$. A general tendency towards increased stability of complexes bearing the 1-methylimidazole leaving group could be discerned among the investigated metal complexes. Overall, immediate cleavage of the chlorido group was observed for $\mathbf{1} \mathbf{a}-\mathbf{d}$, yielding the respective $[\mathrm{M}-\mathrm{Cl}]^{+}$species. Osmium complexes $\mathbf{1} \mathbf{b}$ and $\mathbf{2} \mathbf{b}$ proved to be the most stable in the tested series. Besides the characteristic peak of $[1 \mathbf{b}-\mathrm{Cl}]^{+}\left(\mathrm{m} / \mathrm{z} 467.04 \pm 0.02, m_{\mathrm{ex}} 467.07\right)$, the spectrum of compound $\mathbf{2} \mathbf{b}$ showed an additional species with the leaving group 1-methylimidazole still coordinated to the metal center, that is, $\left[2\right.$ b] ${ }^{+}\left(m / z 549.09 \pm 0.02, m_{\text {ex }}\right.$ 549.12). Ru" complexes $1 \mathrm{a}$ and $\mathbf{2 a}$ behaved similarly to the respective osmium compounds $\mathbf{1} \mathbf{b}$ and $\mathbf{2} \mathbf{b}$. In accordance with its osmium equivalent $\mathbf{2} \mathbf{b}$, ruthenium complex $\mathbf{2}$ a showed a corresponding peak representing the species with the leaving group bound to the metal center during the first $6 \mathrm{~h}$ of incubation, that is, $[2 \mathrm{a}]^{+}$ ( $\left.m / z 459.04 \pm 0.02, m_{\text {ex }} 459.07\right)$, besides the peak pertaining to the complex without its leaving group $[2 \mathbf{a}-M e l m]^{+}(\mathrm{m} / \mathrm{z}$ $\left.377.01 \pm 0.02, m_{\mathrm{ex}} 377.02\right)$. In contrast to the abovementioned occurrence of an additional peak with the azole leaving group attached to the metal center, no such peak was detected in the mass spectra of the corresponding $\mid \mathrm{Ir}^{\mathrm{III}}$ and $\mathrm{Rh}^{\mathrm{III}}$ compounds besides the characteristic $[M \text {-leaving group }]^{+}$peaks $(1 \mathrm{c}, 2 \mathrm{c}$ : $\mathrm{m} / z$ 379.01 $\pm 0.01, m_{\mathrm{ex}} 379.02 ; 1 \mathrm{~d}, 2 \mathrm{~d}: \mathrm{m} / \mathrm{z}$ 469.05 $\pm 0.02, m_{\mathrm{ex}}$ 469.08). Overall, replacement of the labile chlorido ligand by methylimidazole as an $\mathrm{N}$-donor improved the stability of the organometallic complex in aqueous solution, and especially the $\mathrm{Ru}^{\prime \prime}$ and Os" compounds seemed to be more stable under the applied conditions.

\section{Stability of complex $1 \mathrm{c}$ and formation equilibrium processes}

Due to the different behavior observed in the ESI-MS stability experiments, complex formation equilibrium processes of $\mathbf{1} \mathbf{c}$ were studied in aqueous solution by the combined use of $\mathrm{pH}$ potentiometric, ${ }^{1} \mathrm{HNMR}$, and UV/Vis titrations in the absence and presence of chloride ions and compared to the reported data for the ruthenium analogue $\mathbf{1} \mathbf{a}^{[23]}$ The stoichiometry and stability constants of the formed complexes giving the best fits to the experimental data are listed in Table 2.

As chloride ions may possibly coordinate by partly replacing the aqua ligands, the stability constants determined in a chloride-containing medium are regarded as conditional stability constants and are valid only under the given conditions. Thiomaltol can undergo oxidation in the alkaline $\mathrm{pH}$ range, and thus anaerobic conditions were applied. According to pH-potentiometric titration curves recorded at a 1:1 metal-to-ligand ratio, proton displacement by the metal ion was complete at a starting $\mathrm{pH}$ of around 2 in both experimental setups ( $\mathrm{I}=$ $0.2 \mathrm{M} \mathrm{KCl}$ or $\mathrm{KNO}_{3}$ ). Additional signals belonging neither to the methyl protons of the unbound $\mathrm{Rh}^{\text {III-}}-\mathrm{Cp}^{*}$ fragment nor to the ligand were detected at this $\mathrm{pH}$ by ${ }^{1} \mathrm{H}$ NMR spectroscopy (Figure S9). These findings hampered determination of the stability constant of the mono-ligand complex $\left[\operatorname{RhCp}^{*}(\mathrm{~L})\left(\mathrm{H}_{2} \mathrm{O}\right)\right]^{+}$denoted as [ML]. Therefore, UV/Vis spectrophotometry was applied

Table 2. Proton dissociation constant $\left(\mathrm{p} K_{\mathrm{a}}\right)$ of thiomaltol and overall, stepwise, and derived stability constants of its RhCp* complexes in chloride-free and chloride-containing aqueous solutions determined by various methods, and $\mathrm{H}_{2} \mathrm{O} / \mathrm{Cl}^{-}$exchange constant $(\log K)$ for the $\left[\mathrm{ML}\left(\mathrm{H}_{2} \mathrm{O}\right)\right]^{+} \operatorname{complex}\left\{T=25^{\circ} \mathrm{C} ; I=\right.$ $0.20 \mathrm{M}\}^{[a]}$

\begin{tabular}{|c|c|c|c|c|c|}
\hline Constant & Equilibrium & $0.2 \mathrm{M} \mathrm{KNO}_{3}$ & $0.2 \mathrm{M} \mathrm{KCl}$ & Method & Notes \\
\hline $\mathrm{p} K_{\mathrm{a}}(\mathrm{HL})$ & $\mathrm{HL} \rightleftarrows \mathrm{H}+\mathrm{L}$ & $8.16(1)$ & $8.06(1)$ & $\mathrm{pH}$-metry & - \\
\hline $\log K[\mathrm{ML}]$ & $\mathrm{M}+\mathrm{L} \rightleftarrows[\mathrm{ML}]$ & $>15.0$ & $>15.0$ & UV/Vis ( $\mathrm{pH} 0.7-2)$ & estimated; $=\log \beta[\mathrm{ML}]$ \\
\hline $\log K\left[\mathrm{ML}_{2} \mathrm{H}\right]$ & {$[\mathrm{ML}]+\mathrm{HL} \rightleftarrows\left[\mathrm{ML}_{2} \mathrm{H}\right]$} & $4.9(1)$ & $4.9(1)$ & ${ }^{1} \mathrm{H}$ NMR & at $\mathrm{pH} 2.70\left(\mathrm{KNO}_{3}\right) ; \mathrm{pH} 3.85(\mathrm{KCl})$ \\
\hline $\log ß\left[\mathrm{ML}_{2} \mathrm{H}\right]$ & $\mathrm{M}+2 \mathrm{~L}+\mathrm{H} \rightleftarrows\left[\mathrm{ML}_{2} \mathrm{H}\right]$ & $>28.1$ & $>28.0$ & $\begin{array}{l}\text { various methods, } \\
\text { calculated }\end{array}$ & $=\log K\left[\mathrm{ML}_{2} \mathrm{H}\right]+\log K[\mathrm{ML}]+\mathrm{p} K_{\mathrm{a}}(\mathrm{HL})$ \\
\hline \multirow[t]{2}{*}{$\mathrm{p} K_{\mathrm{a}}\left[\mathrm{ML}_{2} \mathrm{H}\right]$} & \multirow[t]{2}{*}[\mathrm{ML}_{2}\mathrm{H}]{$\rightleftarrows\left[\mathrm{ML}_{2}\right]+\mathrm{H}$} & $6.37(1)$ & $6.33(4)$ & ${ }^{1} \mathrm{H}$ NMR & \multirow{5}{*}{$\begin{array}{l}=\log \beta\left[\mathrm{ML}_{2} \mathrm{H}\right]-\log \beta\left[\mathrm{ML}_{2}\right] \\
=\log \beta\left[\mathrm{ML}_{2} \mathrm{H}\right]-\mathrm{p} K_{\mathrm{a}}\left[\mathrm{ML}_{2} \mathrm{H}\right] \\
\log \beta[\mathrm{ML}] \text { and } \log \beta\left[\mathrm{ML}_{2} \mathrm{H}\right] \\
\text { kept constant during the data evaluation } \\
\text { determined at } \mathrm{pH} 3.1\end{array}$} \\
\hline & & 6.4 & 6.2 & pH-metry, calculated & \\
\hline \multirow[t]{2}{*}{$\log \beta\left[\mathrm{ML}_{2}\right]$} & \multirow[t]{2}{*}{$\mathrm{M}+2 \mathrm{~L} \rightleftarrows\left[\mathrm{ML}_{2}\right]$} & $>21.7$ & $>21.7$ & ${ }^{1} \mathrm{H}$ NMR, calculated & \\
\hline & & $>21.6(1)$ & $>21.8(1)$ & pH-metry & \\
\hline $\log K\left(\mathrm{H}_{2} \mathrm{O} / \mathrm{Cl}^{-}\right)$ & {$\left[\mathrm{ML}\left(\mathrm{H}_{2} \mathrm{O}\right)\right]^{+}+\mathrm{Cl}^{-} \rightleftarrows[\mathrm{ML}(\mathrm{Cl})]+\mathrm{H}_{2} \mathrm{O}$} & $0.95(1)$ & $0.95(1)$ & UV/Vis & \\
\hline
\end{tabular}

[a] Charges of the complexes are omitted for simplicity. Standard deviations (SD) are given in parentheses. Hydrolysis products of the organometallic cation: $\log \beta\left[\mathrm{M}_{2} \mathrm{H}_{-2}\right]=-11.12, \log \beta\left[\mathrm{M}_{2} \mathrm{H}_{-3}\right]=-19.01$ at $I=0.20 \mathrm{M}(\mathrm{KCl})$ and $\log \beta\left[\mathrm{M}_{2} \mathrm{H}_{-2}\right]=-8.53, \log \beta\left[\mathrm{M}_{2} \mathrm{H}_{-3}\right]=-14.26$ at $I=0.20 \mathrm{M}\left(\mathrm{KNO}_{3}\right)$ taken from the literature. ${ }^{[22]}$ 
under more dilute conditions in the $\mathrm{pH}$ range $0.7-2.0$ to force dissociation of the complex. These spectra were found to be identical (Figure S10), suggesting that the complex is still intact in this $\mathrm{pH}$ range due to its outstandingly high stability, similar to that of $\mathbf{1} \mathbf{a}^{[23]}$ Therefore, only a threshold limit could be estimated for $\log \beta$ [ML] (Table 2). It is noteworthy that thiomaltol forms significantly more stable complexes than analogous $(O, O)$-hydroxypyrones, with $\log \beta$ values at least six orders of magnitude higher. ${ }^{[21]}$ Deprotonation of $\left[\operatorname{RhCp}^{*}(\mathrm{~L})\left(\mathrm{H}_{2} \mathrm{O}\right)\right]^{+}$was observed at $\mathrm{pH}>6$, leading to precipitation of the product (Figure 4).

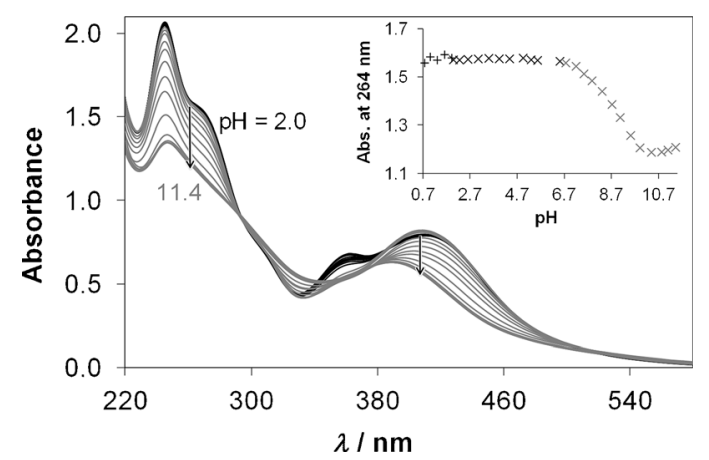

Figure 4. UV/Vis spectra recorded for the $\left[\mathrm{RhCp} *\left(\mathrm{H}_{2} \mathrm{O}\right)_{3}\right]^{2+}$-thiomaltol (1:1) system in the $\mathrm{pH}$ range 2.0-11.4. The inset shows the $\mathrm{pH}$-dependence of absorbance values at $264 \mathrm{~nm}$ at $\mathrm{pH}>2(\times)$ and in the $\mathrm{pH}$ range $0.7-2.0$ using individual samples $(+)\left\{c_{\mathrm{L}}=48 \mu \mathrm{M} ; c_{\mathrm{M}}=48 \mu \mathrm{M} ; T=25^{\circ} \mathrm{C} ; I=0.20 \mathrm{M}(\mathrm{KCl} / \mathrm{HCl})\right.$; $I=2 \mathrm{~cm}\}$.

The speciation in the RhCp*-thiomaltol system was found to be different and more complicated in the presence of excess ligand compared to the complexes of other types of bidentate $\mathrm{O}, \mathrm{O}-, \mathrm{O}, \mathrm{N}-$, or $\mathrm{N}, \mathrm{N}$-ligands, ${ }^{[21-23]}$ since the latter form exclusively mono-ligand $[\mathrm{ML}]$ and $[\mathrm{ML}(\mathrm{OH})]$ complexes in aqueous solution. Careful analysis of the ${ }^{1} \mathrm{H}$ NMR spectra recorded at various metal-to-ligand ratios revealed the formation of bis-ligand complexes of thiomaltol, besides the respective species [ML], in which an additional thiomaltol ligand coordinates in a monodentate fashion through its thio group (Scheme S1 and Figures S11 and S12). Similar mixed coordination modes have been reported for the $\mathrm{Ru}^{\prime \prime}(p$-cym) complexes of hydroxypyr-

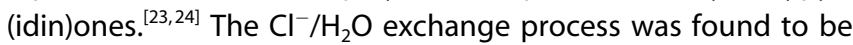
fast (Figure S13) and the obtained $\log K\left(\mathrm{H}_{2} \mathrm{O} / \mathrm{Cl}^{-}\right)$of 0.95 is similar to those obtained for the RhCp* complexes of hydroxypyr(idin)ones with an 0,O-donor set (maltol: 1.17, allomaltol: $1.38,{ }^{[22]}$ deferiprone: $0.78,{ }^{[25]}$ and the Ru' $(p$-cym) complex of thioallomaltol: $0.71^{[23]}$ ), although it is considerably lower than the values obtained for the biologically inactive complexes with $\mathrm{N}, \mathrm{N}$-donor ligands $2,2^{\prime}$-bipyridine or ethylenediamine. ${ }^{[26]}$

\section{Investigation of amino acid interaction by ESI-MS}

In order to acquire more detailed information about the behavior of the synthesized complexes in biological media and with regard to possible binding partners on entering the body by intravenous administration, their reactivity towards the amino acids glycine, L-histidine, and L-cysteine was tested. As previously demonstrated in the literature, ${ }^{[13]}$ in the presence of amino acids or proteins such as ubiquitin, ruthenium(II) (thio)pyr(id)one compounds react with these molecules by cleavage of the ligand scaffold, forming adducts of the form [(p-cym) Ru+Ub/amino acid] ${ }^{+}$. Whereas this effect is observed to a great extent within the first few hours in the case of 0,0 -coordinating ligands, the thiomaltolato complex was found to persist for longer in the presence of the tested biomolecules. Only after $24 \mathrm{~h}$ of incubation were the first biomolecule adducts and ligand release detected. To investigate the change in stability imparted by the introduction of the 1-methylimidazole leaving group, the two ruthenium compounds 1 a and $2 \mathrm{a}$ as well as the two rhodium complexes $1 \mathrm{c}$ and $2 \mathrm{c}$ were chosen. Samples were prepared as described in the Experimental Section. Investigation of compound 1 a revealed the formation of L-histidine (His) adducts after $6 \mathrm{~h}[1 \mathbf{a}-\mathrm{Cl}+\mathrm{His}]^{+}(\mathrm{m} / \mathrm{z}$ $\left.532.10 \pm 0.02, m_{\mathrm{ex}} 532.08\right)$. After $24 \mathrm{~h}$ of incubation, the thiomaltol ligand was cleaved, giving rise to His- as well as L-cysteine (Cys)-containing adducts $[(p-c y m) R u+H i s]^{+}(m / z$ 390.05 \pm $\left.0.02, m_{\mathrm{ex}} 390.08\right)$ and $[(p-\mathrm{cym}) \mathrm{Ru}+\mathrm{Cys}]^{+}\left(\mathrm{m} / \mathrm{z} 356.01 \pm 0.02, m_{\mathrm{ex}}\right.$ 356.03). In general, the formation of L-histidine adducts seems to be favored in the recorded spectra of 1 a compared to L-cysteine coordination. In the spectrum recorded after $48 \mathrm{~h}$, a small amount of a ligand-bearing dimeric species [(pcym $\left.)_{2} \mathrm{Ru}_{2} \mathrm{~L} 1(\mathrm{OH})_{2}\left(\mathrm{CH}_{3} \mathrm{OH}\right)\right]^{+}$( $m / z$ 678.10, $m_{\text {ex }}$ 678.06) was detected. In the case of $\mathbf{2 a}$, increased stability compared to its chlorido analogue can be inferred since the intact compound $[2 \mathrm{a}-\text { Melm }]^{+}$was detected throughout the whole incubation period. During the first $6 \mathrm{~h}$ of incubation, only two species could be observed, namely $\left[2 \mathrm{a}-\right.$ Melm] ${ }^{+}\left(\mathrm{m} / \mathrm{z}\right.$ 377.01, $\mathrm{m}_{\mathrm{ex}}$ 377.02) and $[2 \mathrm{a}]^{+}\left(m / z\right.$ 459.04 $\pm 0.02, m_{\text {ex }}$ 459.07). After $6 \mathrm{~h}$, the adduct $[2 \mathrm{a}-\mathrm{Melm}+\mathrm{His}]^{+}\left(\mathrm{m} / z\right.$ 532.10 $\pm 0.02, m_{\mathrm{ex}}$ 532.08) was found besides the two intact compound species described above. Cleavage of the ligand had only occurred to a very small extent after $24 \mathrm{~h}$, leading to the species [(p-cym)Ru+ $\mathrm{His}]^{+}$and $[(p-c y m) \mathrm{Ru}+\mathrm{Cys}]^{+}$. Equal amounts of three species were found after $48 \mathrm{~h}$ of incubation: $[2 \mathrm{a}-\mathrm{Melm}]^{+}(\mathrm{m} / \mathrm{z}$ 377.10, $m_{\mathrm{ex}}$ 377.02), [(p-cym)Ru+His $]^{+}\left(m / z \quad 390.05 \pm 0.02, m_{\mathrm{ex}} 390.08\right)$, and the ligand-bearing dimeric species $\left[(p-c y m)_{2} \mathrm{Ru}_{2}\right.$ $\left.\mathbf{L} 1(\mathrm{OH})_{2}\left(\mathrm{CH}_{3} \mathrm{OH}\right)\right]^{+}\left(\mathrm{m} / \mathrm{z}\right.$ 678.10, $m_{\mathrm{ex}}$ 678.06). Enhanced stability was also observed for the 1-methylimidazole-bearing organorhodium complex $2 \mathrm{c}$ compared to the chlorido analogue $1 \mathrm{c}$. After just $3 \mathrm{~h}, 1 \mathrm{c}$ had started to form the $\left[\left(C p^{*}\right) \mathrm{Rh}+\mathrm{Cys}\right]$ adduct ( $\left.m / z 358.01 \pm 0.02, m_{\mathrm{ex}} 358.03\right)$, which became the predominant species at the end of the incubation period along with $\left[\left(\mathrm{Cp}^{*}\right) \mathrm{Rh}+\mathrm{His}\right]^{+}\left(\mathrm{m} / \mathrm{z} 392.05 \pm 0.02, m_{\mathrm{ex}}\right.$ 392.08). In contrast, $2 \mathrm{c}$ resisted ligand cleavage induced by amino acid binding for more than $24 \mathrm{~h}$, and this was found only to a very small degree thereafter. Therefore, substitution of the labile chlorido group by 1-methylimidazole is a successful strategy to increase the stability of the organometallic thiomaltol complexes, enabling them to reach tumor tissue intact, in contrast to the respective chlorido analogues or complexes with comparable $0, O$-coordinating ligands. 


\section{pH-Dependent cleavage of the 1-methylimidazole leaving group}

Given the indication of a characteristically lowered $\mathrm{pH}$ level by 0.5 to 1 units in tumor tissues, depending on the size and tumor type, ${ }^{[14,27]}$ the behavior of the synthesized compounds under $\mathrm{pH}$ variation was of great interest. Thus, $\mathrm{pH}$-dependent stability studies of complexes $\mathbf{2} \mathbf{a}-\mathbf{d}$ were conducted by ${ }^{1} \mathrm{H}$ NMR measurements in order to gain knowledge about the formation of the respective aqua species upon $\mathrm{pH}$-induced cleavage of the coordinated azole ligand. In general, all four complexes behaved very similarly on varying the $\mathrm{pH}$. Compounds $\mathbf{2}$ a- $\mathbf{d}$ were dissolved in $\mathrm{D}_{2} \mathrm{O}$, and $\mathrm{pD}$ values were adjusted by the addition of $\mathrm{DCl}$ and $\mathrm{NaOD}$ over a wide $\mathrm{pH}$ range (2.5-12). The obtained $\mathrm{pD}$ values were converted to the corresponding $\mathrm{pH}$ values according to Equation (2), as described in the Experimental Section. The shifts of the 1-methylimidazole and arene signals were monitored, and in the case of compounds $\mathbf{2} \mathbf{a}$ and $\mathbf{2} \mathbf{b}$ the formation of the aqua species led to an additional set of signals corresponding to the aromatic cymene protons. The intact complexes exhibited four signals corresponding to the four aromatic protons, whereas the replacement of the leaving group by a water molecule led to the appearance of two broad peaks in the aromatic region. Another indication of the formation of the aqua species was provided by the emergence of peaks attributable to the free 1methylimidazole ligand. These signals were also used to assess the behavior of compounds $\mathbf{2} \mathbf{c}$ and $\mathbf{2} \mathbf{d}$ under $\mathrm{pH}$ variation. Formation of the respective aqua species could be observed starting at $\mathrm{pH} 6$, until it became the predominant species at values around $\mathrm{pH} 3.5$ (Figure 5). Complexes $\mathbf{2} \mathbf{a}-\mathbf{d}$ showed very high stabilities under alkaline conditions and no degradation products could be detected at up to $\mathrm{pH} 11$ (Table S15 in the Supporting Information). Based on these findings, it can be assumed that under the hypoxic conditions of the tumor microenvironment, the leaving group may be partly cleaved to form the corresponding more reactive aqua complex.

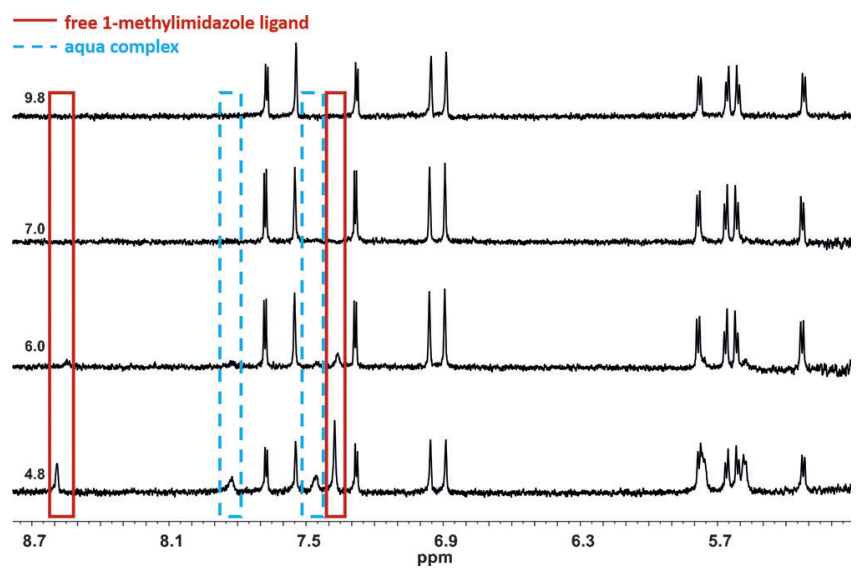

Figure 5. ${ }^{1} \mathrm{H}$ NMR spectra of compound $2 \mathrm{a}$ in $\mathrm{D}_{2} \mathrm{O}$ at different $\mathrm{pH}$ values (4.8-9.8).

\section{Cytotoxicity}

Analogous maltol and allomaltol $\mathrm{Rh}^{\text {III }} \mathrm{Cp}^{*}$ complexes were recently reported to show moderate anticancer activity against the human cancer cell lines $\mathrm{CH} 1 / \mathrm{PA}-1$ (ovarian teratocarcinoma), SW480 (colon carcinoma), and A549 (non-small cell lung carcinoma). ${ }^{[22]}$ The cytotoxicity of complex $1 \mathrm{a}$ in $\mathrm{CH} 1 / \mathrm{PA}-1$ and SW480 cells has been reported previously, whereas data pertaining to A549 cells have been determined for the first time here. The thiomaltolato complexes $\mathbf{1} \mathbf{a}-\mathbf{2} \mathbf{d}$ and the respective free thiomaltol ligand $\mathbf{L} \mathbf{1}$ were tested against the same human cancer cell lines. In general, all complexes showed $\mathrm{IC}_{50}$ values in the low micromolar to submicromolar range (Table 3 ), and are therefore far more potent than their pyrone analogues. ${ }^{[19]}$ Surprisingly, even the free ligand L1 proved to be highly cytotoxic against the tested cell lines and overall it seems that thiomaltol is the activity-determining factor for this class of complexes. In general, the chlorido complexes $\mathbf{1} \mathbf{b}$ - $\mathbf{d}$ showed similar activities, but were found to be more active than $\mathbf{1}$ a. The two different monodentate leaving groups have only a marginal impact on the activity because the supposed activation of the organometallics requires release of the leaving group. In contrast to the chlorido complexes $\mathbf{1} \mathbf{a}-\mathbf{d}$, a small effect of the metal center on the cytotoxicity was observed for complexes $\mathbf{2 a - d}$. In particular, the $\mathrm{Ru}^{\prime \prime}$ and $\mathrm{Rh}^{\mathrm{II}}$ representatives $\mathbf{2 a}$ and $\mathbf{2 c}$ were found to be more active than their chlorido counterparts by factors of up to 3.7, depending on the cell line. The P-glycoprotein (P-gp) expressing cell line SW480 proved to be as sensitive to most of the complexes as the broadly chemosensitive $\mathrm{CH} 1 / \mathrm{PA}-1$ cell line, whereas $\mathrm{IC}_{50}$ values against the more chemoresistant cell line A549 were up to ten-fold higher. This feature of the investigated set of compounds is in sharp contrast to the well-established $\mathrm{Pt}^{\prime \prime}$ complexes, such as cisplatin, which is about 20 times less potent against SW480 than against $\mathrm{CH} 1$ cells (data taken from the literature) ${ }^{[28]}$ As SW480 cells express low levels of $A B C B 1(P-g p)^{[29]}$ and $A 549$ cells overexpress multiple transporters of the $A B C$ family (e.g., $A B C C 2$ (MRP2), $A B C C 4$ (MRP4), ABCC5 (MRP5)), ${ }^{[30-32]}$ investigations concerning the influence of such transporters on the activity of organometallic complexes will be a subject of future research.

\section{Topoisomerase Il $\alpha$ inhibition}

Topoisomerase Il $\alpha$ is an essential nuclear enzyme involved in almost every aspect of DNA functionality: replication, transcription, recombination, and chromosome condensation. Topoisomerase Il $\alpha$ is a primary target for active anticancer drugs. Several studies have revealed that clinically active drugs that target topoisomerase Il $\alpha$ generate enzyme-mediated DNA damage. ${ }^{[35-37]}$ The compounds reported here were studied by a DNA relaxation assay for their topoisomerase Il $\alpha$ inhibitory properties. Complexes $\mathbf{1} \mathbf{a}-\mathbf{d}$ and $\mathbf{2} \mathbf{b}-\mathbf{d}$ displayed inhibitory capacity at a concentration of $10 \mu \mathrm{M}$. In addition, the $\mathrm{Ru}^{\prime \prime}$ complex 2 a proved to be a potent enzyme inhibitor at just $2.5 \mu \mathrm{M}$, which is in contrast to the comparatively high $\mathrm{IC}_{50}$ values of $2 \mathrm{a}$ within the series of 1-methylimidazole-substituted compounds. In comparison, the corresponding ligand L1 did not inhibit the 


\begin{tabular}{|c|c|c|c|c|}
\hline \multirow[b]{2}{*}{ Compound } & \multirow[b]{2}{*}{$M$} & \multicolumn{2}{|c|}{$\mathrm{IC}_{50}$ value $\pm \mathrm{SD}$} & \multirow[b]{2}{*}{ SW480 } \\
\hline & & A549 & $\mathrm{CH} 1 / \mathrm{PA}-1$ & \\
\hline $1 \mathrm{a}$ & $\mathrm{Ru}^{\prime \prime}$ & $12 \pm 4$ & $3 \pm 1$ & $11 \pm 1$ \\
\hline $1 \mathrm{~b}$ & Os" & $4.1 \pm 0.3$ & $2.0 \pm 0.2$ & $2.0 \pm 0.2$ \\
\hline $1 \mathrm{c}$ & $\mathrm{Rh}^{\prime \prime \prime}$ & $5.9 \pm 0.8$ & $1.0 \pm 0.1$ & $1.0 \pm 0.1$ \\
\hline $1 \mathrm{~d}$ & $\mid r^{|I|}$ & $5.8 \pm 1.7$ & $0.57 \pm 0.03$ & $0.7 \pm 0.1$ \\
\hline $2 a$ & $R u^{\prime \prime}$ & $7.1 \pm 1.6$ & $2.6 \pm 0.5$ & $3.0 \pm 0.2$ \\
\hline $2 \mathrm{~b}$ & Os" & $6.6 \pm 0.4$ & $3.0 \pm 0.4$ & $3.4 \pm 0.7$ \\
\hline $2 c$ & $\mathrm{Rh}^{\mathrm{III}}$ & $2.6 \pm 0.6$ & $0.9 \pm 0.2$ & $0.48 \pm 0.03$ \\
\hline $2 d$ & $\mid r^{\prime I I}$ & $3.4 \pm 0.8$ & $0.6 \pm 0.1$ & $0.67 \pm 0.04$ \\
\hline L1 & - & $1.3 \pm 0.8$ & $0.52 \pm 0.04$ & $0.55 \pm 0.31$ \\
\hline cisplatin $^{\text {[a] }}$ & $\mathrm{Pt}^{\|}$ & $1.3 \pm 0.4$ & $0.16 \pm 0.03$ & $3.5 \pm 0.3$ \\
\hline NKP-1339 & $\mathrm{Ru}^{\mathrm{III}}$ & $156 \pm 11$ & $50 \pm 6$ & $62 \pm 9$ \\
\hline
\end{tabular}

enzyme appreciably at the applied concentrations. Figures 6 and 7 show that the tested compounds did not act as topoisomerase poisons, since the linear DNA band was only present in the positive control, whereby the action of the poison generates a high level of Topoll-DNA covalent complexes, resulting in the accumulation of DNA double-strand breaks. It is more likely that the tested complexes act as catalytic inhibitors, blocking the ATP-binding site of the enzyme, preventing binding of the enzyme to DNA or the release of DNA. ${ }^{[36]}$ Similar behavior in the presence of topoisomerase ll $\alpha$ was observed for $\mathrm{Ru}^{\text {"I }}$ and $\mathrm{Rh}^{\mathrm{III}}$ complexes of comparable architecture, with inhibitory effects on topoisomerase $\| \alpha$ starting at concentrations between 5 and $20 \mu \mathrm{m}^{[38,39]}$

\section{Cell cycle and ROS studies}

Since the tested compounds exhibited properties of topoisomerase Il $\alpha$ catalytic inhibitors and may disrupt some essential processes, such as transcription and replication, we examined the changes in cell cycle distribution by flow cytometry using propidium iodide staining. As illustrated in Figure 8 , the effects on SW480 cells after $12 \mathrm{~h}$ of treatment were pronounced: the highest S-phase accumulations were seen for ruthenium(II) and iridium(III) complexes ( $\mathbf{2} \mathbf{a}$ and $\mathbf{2} \mathbf{d}$ ), with an increase to around $45 \%$ at a concentration of $20 \mu \mathrm{m}$. Detailed cell cycle distribution data are summarized in Table S16.

Furthermore, we investigated whether the thiomaltol-based organometallic complexes could alter the levels of reactive oxygen species (ROS) in cancer cells (Figure 9) by means of a $2^{\prime}, 7^{\prime}$-dichlorofluorescein diacetate (DCF-DA) assay. It has been reported by Sadler and co-workers that certain organoruthenium complexes are able to catalytically reduce GSH levels, leading to an increase of ROS formation. ${ }^{[40,41]}$ Our complexes were studied with regard to their potential to raise cellular ROS levels, and the obtained data indicated slight increases in ROS levels for the rhodium(III) 1-methylimidazole-substituted complex $\mathbf{2} \mathrm{c}$ by a factor of 2.7 and for the iridium(III) 1-methylimidazole-substituted complex $\mathbf{2} \mathbf{d}$ by a factor of 1.5 , but no discernible effect for the other tested substances. Table S17 shows the

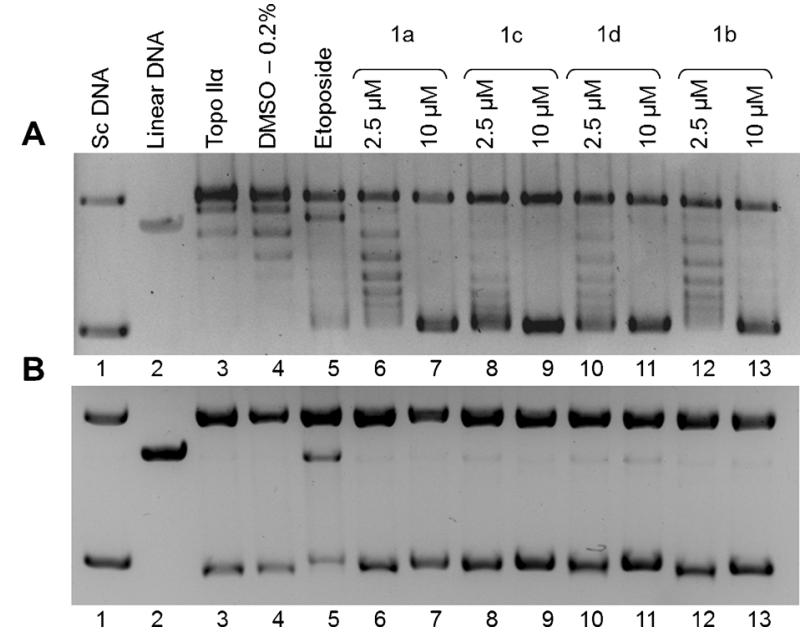

Figure 6. Topoisomerase Il $\alpha$-inhibitory capacities of complexes $\mathbf{1}$ a-d determined by the plasmid DNA relaxation assay. Supercoiled and linear DNA used as references (lanes 1 and 2, respectively); relaxed DNA bands (lane 3) indicating intact enzyme activity; DMSO control corresponding to maximum content in test compound solutions (lane 4); linear DNA band induced by $0.8 \mathrm{~mm}$ etoposide (positive control, lane 5). Lanes 6-13 display the reaction of topoisomerase $\| \alpha$ with supercoiled DNA in the presence of the test compounds. The top gel (A) was post-stained and the bottom gel (B) was prestained with $0.7 \mu \mathrm{g} \mathrm{mL}^{-1}$ ethidium bromide.

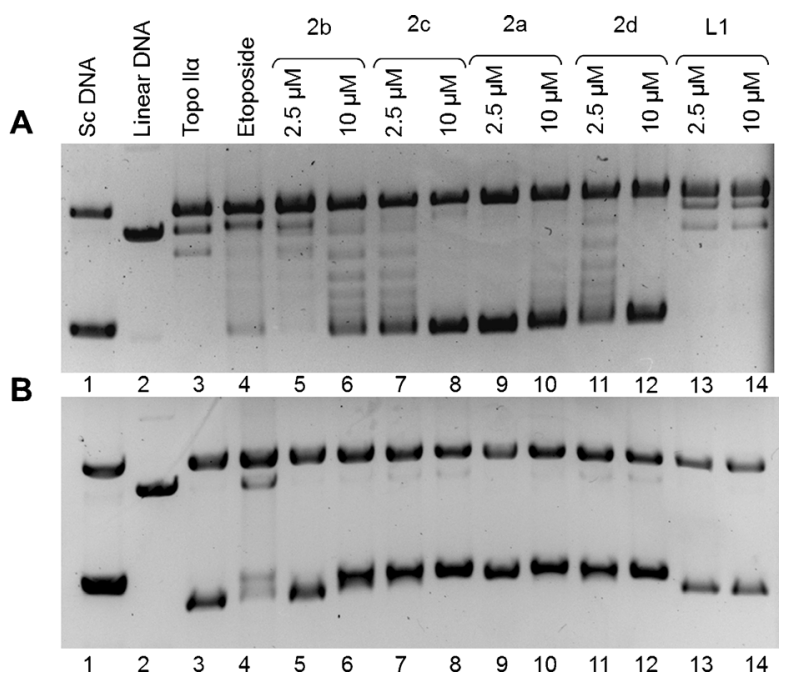

Figure 7. Topoisomerase Il $\alpha$-inhibitory capacities of complexes $\mathbf{2} \mathbf{a}-\mathbf{d}$ and ligand $\mathbf{L} 1$ determined by the plasmid DNA relaxation assay. Supercoiled and linear DNA used as references (lanes 1 and 2, respectively); relaxed DNA bands (lane 3 ) indicating intact enzyme activity; linear DNA band induced by $0.8 \mathrm{~mm}$ etoposide (positive control, lane 4). Lanes 5-14 display the reaction of topoisomerase Il $\alpha$ with supercoiled DNA in the presence of the test compounds. The top gel (A) was post-stained and the bottom gel (B) was pre-stained with $0.7 \mu \mathrm{g} \mathrm{mL}^{-1}$ ethidium bromide.

detailed ROS generation data. Based on these findings, the formation of ROS does not convincingly contribute to the cytotoxicity of thiopyrone-based organometallics.

In summary, these results suggest that topoisomerase Il $\alpha$ may be a target for organometallic thiomaltol-based complexes, whereas the free ligand is devoid of enzyme inhibitory 


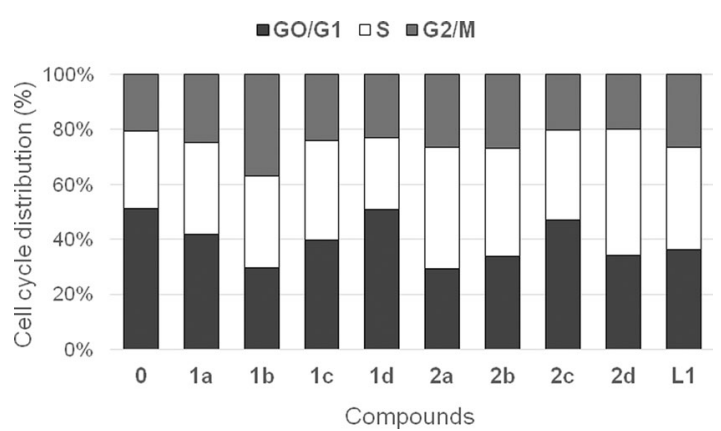

Figure 8. Concentration-dependent impact of thiomaltol-based organometallic complexes $\mathbf{1} \mathbf{a}-\mathbf{d}$ and $\mathbf{2} \mathbf{a}-\mathbf{d}$ and the corresponding ligand $\mathbf{L} \mathbf{1}$ at a concentration of $20 \mu \mathrm{m}$ on the cell-cycle distribution of SW480 cells after $12 \mathrm{~h}$ of continuous exposure.

properties at the same concentration. None of these compounds act as topoisomerase Il $\alpha$ poisons. Cell cycle distribution analyses revealed a moderate increase of the S-phase fraction upon exposure to the organometallics, consistent with inhibition of this key enzyme. In addition, ROS production appears unlikely to play a central role in the cellular response to treatment with these metal complexes. A general overview of cytotoxicity, enzyme inhibition, cell cycle perturbations, and ROS activation of thiomaltol-based complexes suggests that metal coordination has a distinct impact on the biological activity.

\section{Conclusions}

Thiomaltol-based organometallics are characterized by increased stability compared to their pyrone analogues, making them more suitable for metallodrug development. In this work, thiomaltol-bearing complexes with $\mathrm{Ru}^{\prime \prime}, \mathrm{Os}^{\prime \prime}, \mathrm{Rh}{ }^{\mathrm{II \prime}}$, and Ir"', bearing either 1-methylimidazole or chloride as leaving group, have been synthesized, and the effects of different metal centers and leaving groups on the physicochemical and biological properties have been investigated. The acquired data implied that the introduction of 1-methylimidazole as a leaving group substantially increases the stability in aqueous solution and shields the complex from coordination of biomolecules that would lead to ligand release. This modification may allow accumulation of the intact complexes and controlled activation at the lower $\mathrm{pH}$ values within tumor tissues. The synthesized substances were tested against three different human cancer cell lines with regard to their anticancer potential, and promising $\mathrm{IC}_{50}$ values in the low $\mu \mathrm{M}$ to sub- $\mu \mathrm{M}$ range were observed. Whereas the complexes proved to be good topoisomerase Il $\alpha$ inhibitors, the thiomaltol ligand alone proved to be inactive and the tested substances were evidently not poisons to the enzyme. The complexes induce changes in the cell cycle, such that an accumulation of cells in the S-phase was observed. According to these findings, topoisomerase Il $\alpha$ might be a possible target of organometallic thiopyrones. Based on the data presented herein, thiomaltol-based organometallic complexes can be regarded as promising candidates for the further development of anticancer agents with topoisomerase Il $\alpha$ inhibitory properties.

A
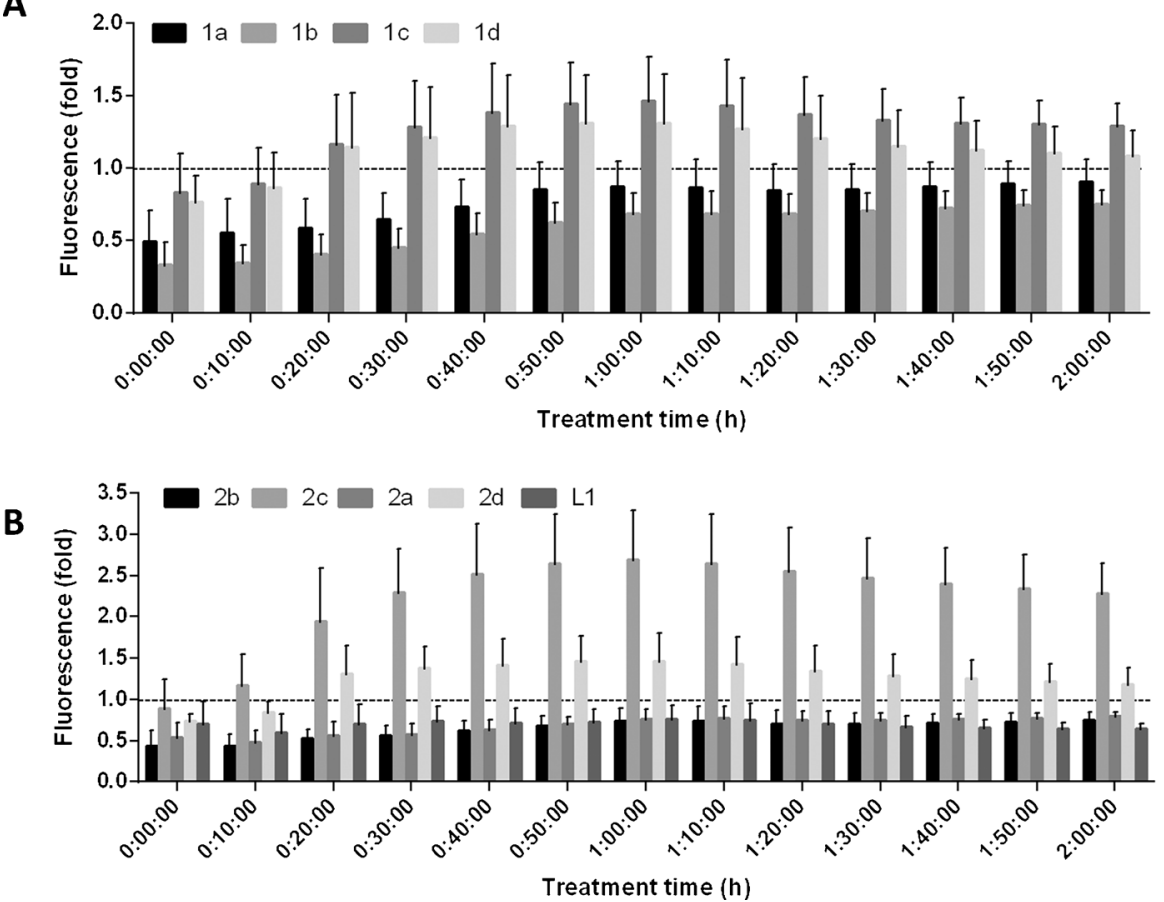

Figure 9. Generation of ROS as indicated by DCF-DA microplate assay using complexes: A) $\mathbf{1}$ a-d, B) $\mathbf{2}$ a-d and L1. Mean \pm standard deviation is plotted for three replicates at each concentration. The relative fluorescence unit (RFU) for all samples was normalized to the RFU of stained untreated control (indicated by a dashed line). 


\section{Experimental Section}

\section{Materials}

The dimeric metal precursors $\left[\mathrm{Ru}(p-c y m) \mathrm{Cl}_{2}\right]_{2}$, $\left[\mathrm{Os}(p-c y m) \mathrm{Cl}_{2}\right]_{2}$, $\left[\mathrm{Rh}\left(\mathrm{Cp}^{*}\right) \mathrm{Cl}_{2}\right]_{2}$, and $\left[\mathrm{Ir}\left(\mathrm{Cp}^{*}\right) \mathrm{Cl}_{2}\right]_{2}$ were prepared according to literature procedures. ${ }^{[16,42,43]}$ The solvents used were purchased from commercial sources and distilled prior to use. Methanol (HPLC grade, Fisher) and Millipore water (MilliQ $\mathrm{H}_{2} \mathrm{O} ; 18.2 \mathrm{M} \Omega$; Synergy 185 UV Ultrapure Water System, Millipore) were used for mass spectrometric investigations and titrations. 3-Hydroxy-2-methyl-4H-pyran-4one ( $\geq 99.0 \%$, Aldrich), Lawesson's reagent ( $99 \%$, Acros), osmium(VIII) tetroxide (Johnson Matthey), hydrazine dihydrochloride (>98\%, Aldrich), hydrochloric acid (37\%, Acros), $\alpha$-terpinene $(90 \%$, Acros), iridium(III) chloride (Johnson Matthey), 1,2,3,4,5-pentamethylcyclopentadiene (95\%, Aldrich), ruthenium(III) chloride hydrate (Johnson Matthey), rhodium(III) chloride hydrate (Johnson Matthey), 1-methylimidazole (99\%, Aldrich), sodium methoxide (ca. $95 \%$, Fluka), sodium hexafluorophosphate (98\%, Aldrich), glycine (Merck), L-cysteine (Fluka), and L-histidine (Merck) were purchased and used as received. $\mathrm{KCl}, \mathrm{KNO}_{3}, \mathrm{AgNO}_{3}, \mathrm{HCl}, \mathrm{HNO}_{3}, \mathrm{KOH}$, and 4,4dimethyl-4-silapentane-1-sulfonic acid (DSS) were purchased from Sigma-Aldrich in puriss quality. NMR spectra were recorded at $25^{\circ} \mathrm{C}$ on a Bruker Avance $1 \mathrm{II}^{\mathrm{TM}} 500 \mathrm{MHz}$ FT-NMR spectrometer. ${ }^{1} \mathrm{H}$ NMR spectra were measured at $500.10 \mathrm{MHz}$ and ${ }^{13} \mathrm{C}$ NMR spectra at $125.75 \mathrm{MHz}$ from solutions in deuterated dimethyl sulfoxide, methanol, or chloroform. DCl (35\%) and $\mathrm{NaOD}(4 \%)$ were used for the stability investigation of complexes at varying $\mathrm{pH}$ values. CHNS elemental analyses were carried out on a Eurovector EA3000 elemental analyzer in the microanalytical laboratory of the University of Vienna.

\section{General procedures}

General procedure for the synthesis of Os"/Ru" cymene and Ir"II/

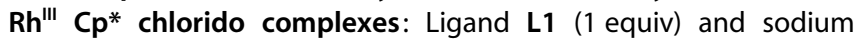
methoxide (1.1 equiv) were dissolved in absolute methanol and the solution was stirred for $15 \mathrm{~min}$ under inert conditions. The yellow solution was then transferred to a Schlenk flask containing the respective dimer ( 0.45 equiv), whereupon it underwent an immediate color change. The mixture was stirred under argon atmosphere at $40^{\circ} \mathrm{C}$ for $1.5 \mathrm{~h}$. Thereafter, the solvent was evaporated under reduced pressure and the residue was redissolved in dichloromethane. Filtration allowed the removal of reaction by-products, and the filtrate was concentrated in vacuo. Precipitation from $n$-hexane afforded the pure product in good to excellent yields (63-92\%).

General procedure for the synthesis of Os"/Ru" cymene and Ir"I// $\mathbf{R h}^{\text {III }} \mathbf{C p}^{*}$ 1-methylimidazole complexes: The ligand L1 (1 equiv) and sodium methoxide (1.1 equiv) were dissolved in absolute methanol and the solution was stirred for 15 min under inert conditions. The yellow solution was then transferred to a Schlenk flask containing the respective precursor complex (0.9 equiv), whereupon it underwent an immediate color change. The mixture was stirred under argon atmosphere at $40^{\circ} \mathrm{C}$ for $4-48 \mathrm{~h}$, depending on the relevant precursor metal complex. In order to separate the desired product from uncharged side products, sodium hexafluorophosphate was added and the resulting mixture was stirred for a further $1 \mathrm{~h}$ at room temperature. Thereafter, the solvent was evaporated under reduced pressure and the residue was taken up in dichloromethane. Filtration allowed the removal of reaction byproducts and the filtrate was concentrated in vacuo. Precipitation from dichloromethane/diethyl ether afforded the pure product in low to moderate yields (32-52\%).
[Chlorido(2-methyl-3-(oxo- $\mathrm{\kappa} O)$-pyran-4(1H)-thionato- $\kappa S)\left(\eta^{6}-p-\right.$ cymene)osmium(II)] (1 b): The reaction was performed according to the general procedure for chlorido complexes using L1 $(60 \mathrm{mg}$, $0.42 \mathrm{mmol}$, 1 equiv), sodium methoxide $(25 \mathrm{mg}, 0.46 \mathrm{mmol}$, 1.1 equiv), and $\left[\left(\eta^{6}-p-c y m\right) O s^{\prime \prime} \mathrm{Cl}_{2}\right]_{2}(150 \mathrm{mg}, 0.19 \mathrm{mmol}, 0.45$ equiv). The product was isolated as a red solid. Yield: $135 \mathrm{mg}(71 \%)$. ${ }^{1} \mathrm{H}$ NMR $\left(500.10 \mathrm{MHz}, \mathrm{CDCl}_{3}, 25^{\circ} \mathrm{C}\right): \delta=1.28\left(\mathrm{~d},{ }^{3} \mathrm{~J}(\mathrm{H}, \mathrm{H})=7 \mathrm{~Hz}, 6 \mathrm{H}\right.$; $\left.\mathrm{CH}_{3, \text { cym }}\right), 2.33\left(\mathrm{~s}, 3 \mathrm{H} ; \mathrm{CH}_{3, \text { cym }}\right), 2.51\left(\mathrm{~s}, 3 \mathrm{H} ; \mathrm{CH}_{3}\right), 2.67-2.75(\mathrm{~m}, 1 \mathrm{H}$; $\left.\mathrm{CH}_{\text {cym }}\right), 5.62\left(\mathrm{brs}, 2 \mathrm{H} ; \mathrm{CH}_{\mathrm{Ar}}\right), 5.82\left(\mathrm{brs}, 2 \mathrm{H} ; \mathrm{CH}_{\mathrm{Ar}}\right), 7.26\left(\mathrm{~d},{ }^{3} \mathrm{~J}(\mathrm{H}, \mathrm{H})=\right.$ $5 \mathrm{~Hz}, 1 \mathrm{H} ; \mathrm{CH}-5), 7.43 \mathrm{ppm}\left(\mathrm{d},{ }^{3} \mathrm{~J}(\mathrm{H}, \mathrm{H})=5 \mathrm{~Hz}, 1 \mathrm{H} ; \mathrm{CH}-6\right) ;{ }^{13} \mathrm{C} \mathrm{NMR}$ $\left(125.75 \mathrm{MHz}, \mathrm{CDCl}_{3}, 25^{\circ} \mathrm{C}\right): \delta=15.4\left(\mathrm{CH}_{3}\right), 18.5\left(\mathrm{CH}_{3, \mathrm{cym}}\right), 22.4 \& 22.9$ $\left(2 \mathrm{CH}_{3, \mathrm{cym}}\right), 31.4\left(\mathrm{CH}_{\mathrm{cym}}\right), 73.2\left(\mathrm{CH}_{\mathrm{Ar}}\right), 75.0\left(\mathrm{CH}_{\mathrm{Ar}}\right), 90.3\left(\mathrm{C}_{\mathrm{q}, \mathrm{Ar}}\right), 90.8$ $\left(\mathrm{C}_{\mathrm{q}, \mathrm{Ar}}\right), 120.7(\mathrm{CH}-5), 144.6(\mathrm{CH}-6), 153.5\left(\mathrm{C}_{\mathrm{q}}-2\right), 168.5\left(\mathrm{C}_{\mathrm{q}}-3\right)$, $181.9 \mathrm{ppm}\left(\mathrm{C}_{\mathrm{q}}-4\right)$; elemental analysis calcd (\%) for $\mathrm{C}_{16} \mathrm{H}_{19} \mathrm{ClO}_{2} \mathrm{OsS}$ : $\mathrm{C}$ 38.35, H 3.82, S 6.40; found: C 38.48, H 3.98, S 6.30.

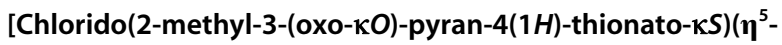
1,2,3,4,5-pentamethylcyclopentadienyl)rhodium(III)] (1 c): The reaction was performed according to the general procedure for chlorido complexes using L1 (78 mg, $0.55 \mathrm{mmol}, 1$ equiv), sodium methoxide (32 mg, $0.60 \mathrm{mmol}, 1.1$ equiv), and $\left[\left(\eta^{5}-\mathrm{Cp}^{*}\right) \mathrm{Rh}^{\prime \prime \prime} \mathrm{Cl}_{2}\right]_{2}$ (150 mg, $0.24 \mathrm{mmol}, 0.45$ equiv). The product was isolated as a red solid. Yield: $189 \mathrm{mg}$ (95\%). ' $\mathrm{H}$ NMR $\left(500.10 \mathrm{MHz}, \mathrm{CDCl}_{3}, 25^{\circ} \mathrm{C}\right): \delta=$ $\left.1.75\left(\mathrm{~s}, 15 \mathrm{H} ; \mathrm{CH}_{3, \mathrm{Cp}}\right)^{*}\right), 2.45\left(\mathrm{~s}, 3 \mathrm{H} ; \mathrm{CH}_{3}\right), 7.17\left(\mathrm{~d},{ }^{3} \mathrm{~J}(\mathrm{H}, \mathrm{H})=5 \mathrm{~Hz}, 1 \mathrm{H}\right.$; $\mathrm{CH}-5), 7.45 \mathrm{ppm}\left(\mathrm{d},{ }^{3} \mathrm{~J}(\mathrm{H}, \mathrm{H})=5 \mathrm{~Hz}, 1 \mathrm{H} ; \mathrm{CH}-6\right) ;{ }^{13} \mathrm{C}$ NMR $(125.75 \mathrm{MHz}$, $\left.\mathrm{CDCl}_{3}, 25^{\circ} \mathrm{C}\right): \delta=9.0\left(\mathrm{CH}_{3, \mathrm{Cp}} \mathrm{p}^{*}\right), 15.5\left(\mathrm{CH}_{3}\right), 94.0\left(\mathrm{~d},{ }^{1} \mathrm{~J}(\mathrm{Rh}, \mathrm{C})=10 \mathrm{~Hz}\right.$; $\left.\mathrm{C}_{\left(\mathrm{C}^{*}\right)}\right), 120.9(\mathrm{CH}-5), 143.7 \quad(\mathrm{CH}-6), 153.7 \quad\left(\mathrm{C}_{\mathrm{q}}-2\right), 165.5 \quad\left(\mathrm{C}_{\mathrm{q}}-3\right)$, $180.0 \mathrm{ppm} \quad\left(\mathrm{C}_{\mathrm{q}}-4\right)$; elemental analysis calcd (\%) for $\mathrm{C}_{16} \mathrm{H}_{19} \mathrm{ClO}_{2} \mathrm{RhS} \cdot 0.5 \mathrm{H}_{2} \mathrm{O}: \mathrm{C} 45.46, \mathrm{H}$ 4.77, $\mathrm{S} 7.59$; found: $\mathrm{C} 45.35, \mathrm{H}$ 4.92, S 7.70 .

[Chlorido(2-methyl-3-(oxo-kO)-pyran-4(1H)-thionato-kS)( $\eta^{5}$ 1,2,3,4,5-pentamethylcyclopentadienyl)iridium(III)] (1d): The reaction was performed according to the general protocol for chlorido complexes using L1 (60 mg, $0.42 \mathrm{mmol}, 1$ equiv), sodium methoxide ( $25 \mathrm{mg}, 0.46 \mathrm{mmol}, 1.1$ equiv), and $\left[\left(\eta^{5}-\mathrm{Cp}^{*}\right) \mid \mathrm{rr}^{\prime \prime \prime} \mathrm{Cl}_{2}\right]_{2}(150 \mathrm{mg}$, $0.19 \mathrm{mmol}, 0.45$ equiv). The product was isolated as a red solid. Yield: $165 \mathrm{mg}(86 \%)$. ${ }^{1} \mathrm{H}$ NMR $\left(500.10 \mathrm{MHz}, \mathrm{CDCl}_{3}, 25^{\circ} \mathrm{C}\right): \delta=1.78$ $\left(\mathrm{s}, 15 \mathrm{H} ; \mathrm{CH}_{3, \mathrm{Cp}}\right)^{*}, 2.52\left(\mathrm{~s}, 3 \mathrm{H} ; \mathrm{CH}_{3}\right), 7.18\left(\mathrm{~d},{ }^{3} \mathrm{~J}(\mathrm{H}, \mathrm{H})=5 \mathrm{~Hz}, 1 \mathrm{H} ; \mathrm{CH}-5\right)$, $7.45 \mathrm{ppm} \quad\left(\mathrm{d},{ }^{3} \mathrm{~J}(\mathrm{H}, \mathrm{H})=5 \mathrm{~Hz}, 1 \mathrm{H} ; \mathrm{CH}-6\right) ;{ }^{13} \mathrm{C} \mathrm{NMR} \quad(125.75 \mathrm{MHz}$, $\left.\mathrm{CDCl}_{3}, 25^{\circ} \mathrm{C}\right): \delta=8.9\left(\mathrm{CH}_{3, \mathrm{C} \mathrm{p}^{*}}\right), 15.5\left(\mathrm{CH}_{3}\right), 86.2\left(\mathrm{~d},{ }^{1} \mathrm{~J}(\mathrm{Ir}, \mathrm{C})=10 \mathrm{~Hz}\right.$; $\left.\mathrm{C}_{\left(\mathrm{C}^{*}\right)}\right), 121.8(\mathrm{CH}-5), \quad 143.7(\mathrm{CH}-6), 154.2\left(\mathrm{C}_{\mathrm{q}}-2\right), 167.7\left(\mathrm{C}_{\mathrm{q}}-3\right)$, $179.4 \mathrm{ppm} \quad\left(\mathrm{C}_{\mathrm{q}}-4\right)$; elemental analysis calcd (\%) for $\mathrm{C}_{16} \mathrm{H}_{20} \mathrm{ClllO}_{2} \mathrm{~S} \cdot \mathrm{H}_{2} \mathrm{O}$ : C 36.81, H 4.25, S 6.14; found: C 36.72, H 3.98, S 6.43.

[(1-Methylimidazole- $\left.\kappa N^{3}\right)$ (2-methyl-3-(oxo- $\left.\kappa O\right)-p y r a n-4(1 H)$-thionato- $\kappa S)\left(\eta^{6}-p\right.$-cymene)ruthenium(II)] hexafluorophosphate (2a): The reaction was performed according to the general procedure for the synthesis of metal complexes with 1-methylimidazole as leaving group, using ligand $\mathbf{L 1}(51 \mathrm{mg}, 0.354 \mathrm{mmol}, 1$ equiv), sodium methoxide ( $21 \mathrm{mg}, 0.390 \mathrm{mmol}, 1.1$ equiv), and $\left[\left(\eta^{6}-p\right.\right.$-cym) $\left.\mathrm{Ru}^{\prime \prime}(\mathrm{Melm})_{2} \mathrm{Cl}\right] \mathrm{Cl}(150 \mathrm{mg}, 0.319 \mathrm{mmol}, 0.9$ equiv). The mixture was stirred at $40^{\circ} \mathrm{C}$ for $40 \mathrm{~h}$, affording the desired product after workup as orange crystals. Yield: $79 \mathrm{mg}(41 \%) .{ }^{1} \mathrm{H}$ NMR $(500.10 \mathrm{MHz}$, $\left[\mathrm{D}_{4}\right]$ methanol, $\left.25^{\circ} \mathrm{C}\right): \delta=1.25-1.28\left(\mathrm{~m}, 6 \mathrm{H} ; \mathrm{CH}_{3, \mathrm{cym}}\right), 2.07(\mathrm{~s}, 3 \mathrm{H}$; $\left.\mathrm{CH}_{3 \text { cym }}\right), 2.50\left(\mathrm{~s}, 3 \mathrm{H} ; \mathrm{CH}_{3}\right), 2.67-2.76\left(\mathrm{~m}, 1 \mathrm{H} ; \mathrm{CH}_{\mathrm{cym}}\right), 3.72(\mathrm{~s}, 3 \mathrm{H}$; $\left.\mathrm{CH}_{3, \mathrm{Melm}}\right), 5.46-5.55\left(\mathrm{~m}, 2 \mathrm{H} ; \mathrm{CH}_{\mathrm{Ar}}\right), 5.69-5.75\left(\mathrm{~m}, 2 \mathrm{H} ; \mathrm{CH}_{\mathrm{Ar}}\right), 6.95(\mathrm{~s}$, $\left.1 \mathrm{H} ; \mathrm{CH}_{\text {Melm }}\right), 7.07\left(\mathrm{~s}, 1 \mathrm{H} ; \mathrm{CH}_{\text {Melm }}\right), 7.28\left(\mathrm{~d},{ }^{3} \mathrm{~J}(\mathrm{H}, \mathrm{H})=5 \mathrm{~Hz}, 1 \mathrm{H} ; \mathrm{CH}-5\right)$, 7.70 (s, $\left.1 \mathrm{H} ; \quad \mathrm{CH}_{\text {Melm }}\right), 7.75 \mathrm{ppm}\left(\mathrm{d},{ }^{3} J(\mathrm{H}, \mathrm{H})=5 \mathrm{~Hz}, 1 \mathrm{H}\right.$; CH-6); ${ }^{13} \mathrm{C} \mathrm{NMR} \quad\left(125.75 \mathrm{MHz},\left[\mathrm{D}_{4}\right]\right.$ methanol, $\left.25^{\circ} \mathrm{C}\right): \delta=13.7\left(\mathrm{CH}_{3}\right), 16.8$ $\left(\mathrm{CH}_{3, \mathrm{cym}}\right), 21.0$ \& $21.7\left(2 \mathrm{CH}_{3, \mathrm{cym}}\right), 30.9\left(\mathrm{CH}_{\mathrm{cym}}\right), 33.2\left(\mathrm{CH}_{3, \mathrm{Melm}}\right), 81.1 \&$ $82.6\left(2 \mathrm{CH}_{\mathrm{Ar}}\right), 83.5 \& 84.6\left(2 \mathrm{CH}_{\mathrm{Ar}}\right), 100.2\left(\mathrm{C}_{\mathrm{q}, \mathrm{Ar}}\right), 103.0\left(\mathrm{C}_{\mathrm{q}, \mathrm{Ar}}\right), 119.8$ $(\mathrm{CH}-5), 121.6\left(\mathrm{CH}_{\text {Melm }}\right), 129.5\left(\mathrm{CH}_{\text {Melm }}\right), 139.8\left(\mathrm{CH}_{\text {Melm }}\right), 145.9$ (C-6), $154.1\left(C_{q}-2\right), 164.9\left(C_{q}-3\right), 180.1$ ppm $\left(C_{q}-4\right)$; elemental analysis calcd 
(\%) for $\mathrm{C}_{20} \mathrm{H}_{25} \mathrm{~F}_{6} \mathrm{~N}_{2} \mathrm{O}_{2}$ PRuS: C 39.80, H 4.18, N 4.64, S 5.31; found: C $39.81, \mathrm{H} 4.14, \mathrm{~N} 4.67$, S 5.23 .

[(1-Methylimidazole- $\left.\kappa N^{3}\right)$ (2-methyl-3-(oxo- $\left.\mathrm{O} O\right)$-pyran-4(1H)-thionato- $\kappa S)\left(\eta^{6}-p\right.$-cymene)osmium(II)] hexafluorophosphate (2b): The reaction was performed according to the general procedure for the synthesis of metal complexes with 1-methylimidazole as leaving group, using ligand L1 (43 $\mathrm{mg}, 0.298 \mathrm{mmol}, 1$ equiv), sodium methoxide (18 mg, $0.328 \mathrm{mmol}, 1.1$ equiv), and [( $\eta^{6}-p$-cym) $\left.\mathrm{Os}^{\prime \prime}(\mathrm{Melm})_{2} \mathrm{Cl}\right] \mathrm{Cl}$ (150 mg, $0.268 \mathrm{mmol}, 0.9$ equiv). The mixture was stirred at $40{ }^{\circ} \mathrm{C}$ for $48 \mathrm{~h}$ affording the desired product after workup as red-brown crystals. Yield: $75 \mathrm{mg}(40 \%)$. ${ }^{1} \mathrm{H}$ NMR $(500.10 \mathrm{MHz}$, $\left[\mathrm{D}_{4}\right]$ methanol, $\left.25^{\circ} \mathrm{C}\right): \delta=1.22-1.28\left(\mathrm{~m}, 6 \mathrm{H} ; \mathrm{CH}_{3, \mathrm{cym}}\right), 2.13(\mathrm{~s}, 3 \mathrm{H}$; $\left.\mathrm{CH}_{3, \mathrm{cym}}\right), 2.53\left(\mathrm{~s}, 3 \mathrm{H} ; \mathrm{CH}_{3}\right), 2.57-2.66\left(\mathrm{~m}, 1 \mathrm{H} ; \mathrm{CH}_{\mathrm{cym}}\right), 3.74(\mathrm{~s}, 3 \mathrm{H}$; $\left.\mathrm{CH}_{3, \mathrm{Melm}}\right), 5.68-5.77\left(\mathrm{~m}, 2 \mathrm{H} ; \mathrm{CH}_{\mathrm{Ar}}\right), 5.85-5.94\left(\mathrm{~m}, 2 \mathrm{H} ; \mathrm{CH}_{\mathrm{Ar}}\right), 6.94(\mathrm{~s}$, $\left.1 \mathrm{H} ; \mathrm{CH}_{\text {Melm }}\right), 7.04\left(\mathrm{~s}, 1 \mathrm{H} ; \mathrm{CH}_{\text {Melm }}\right), 7.36\left(\mathrm{~d},{ }^{3} \mathrm{~J}(\mathrm{H}, \mathrm{H})=5 \mathrm{~Hz}, 1 \mathrm{H} ; \mathrm{CH}-5\right)$, $7.72\left(\mathrm{~s}, 1 \mathrm{H} ; \mathrm{CH}_{\text {Melm }}\right), 7.75 \mathrm{ppm}\left(\mathrm{d},{ }^{3} \mathrm{~J}(\mathrm{H}, \mathrm{H})=5 \mathrm{~Hz}, 1 \mathrm{H} ; \mathrm{CH}-6\right)$; ${ }^{13} \mathrm{C}$ NMR $\left(125.75 \mathrm{MHz}, \quad\left[\mathrm{D}_{4}\right]\right.$ methanol, $\left.25^{\circ} \mathrm{C}\right): \delta=13.8\left(\mathrm{CH}_{3}\right), 16.7$ $\left(\mathrm{CH}_{3, \mathrm{cym}}\right), 21.3$ \& $22.1\left(2 \mathrm{CH}_{3, \mathrm{cym}}\right), 31.1\left(\mathrm{CH}_{\mathrm{cym}}\right), 33.2\left(\mathrm{CH}_{3, \mathrm{Melm}}\right), 71.7 \&$ $73.3\left(2 \mathrm{CH}_{\mathrm{Ar}}\right), 74.9 \& 76.2\left(2 \mathrm{CH}_{\mathrm{Ar}}\right), 92.0\left(\mathrm{C}_{\mathrm{q}, \mathrm{Ar}}\right), 93.3\left(\mathrm{C}_{\mathrm{q}, \mathrm{Ar}}\right), 120.2(\mathrm{CH}-$ 5), $121.4\left(\mathrm{CH}_{\text {Melm }}\right), 128.9\left(\mathrm{CH}_{\text {Melm }}\right), 139.5\left(\mathrm{CH}_{\text {Melm }}\right), 146.7(\mathrm{CH}-6), 154.6$ $\left(\mathrm{C}_{\mathrm{q}}-2\right), 167.5\left(\mathrm{C}_{\mathrm{q}}-3\right), 180.7 \mathrm{ppm}\left(\mathrm{C}_{\mathrm{q}}-4\right)$; elemental analysis calcd (\%) for $\mathrm{C}_{20} \mathrm{H}_{25} \mathrm{~F}_{6} \mathrm{~N}_{2} \mathrm{O}_{2} \mathrm{OsPS}$ : C 34.68, $\mathrm{H}$ 3.64, N 4.04, S 4.63; found: $\mathrm{C}$ $34.69, \mathrm{H} 3.56, \mathrm{~N} 4.02$, S 4.54 .

[(1-Methylimidazole-k $\left.N^{3}\right)$ (2-methyl-3-(oxo-кO)-pyran-4(1H)-thionato- $\kappa S)\left(\eta^{5}-1,2,3,4,5-\right.$ pentamethylcyclopentadienyl)rhodium(III)] hexafluorophosphate $(\mathbf{2 c})$ : The reaction was performed according to the general procedure for the synthesis of metal complexes with 1-methylimidazole as leaving group, using ligand L1 $150 \mathrm{mg}$, $0.352 \mathrm{mmol}$, 1 equiv), sodium methoxide $(21 \mathrm{mg}, 0.387 \mathrm{mmol}$, 1.1 equiv), and $\left[\left(\eta^{5}-\mathrm{Cp}^{*}\right) \mathrm{Rh}^{\mathrm{II \prime}}(\mathrm{Melm})_{2} \mathrm{Cl}\right] \mathrm{Cl} \quad(150 \mathrm{mg}, 0.317 \mathrm{mmol}$, 0.9 equiv). The mixture was stirred at $40^{\circ} \mathrm{C}$ for $4 \mathrm{~h}$, affording the desired product after work-up as orange crystals. Yield: $100 \mathrm{mg}$ (52\%). ${ }^{1} \mathrm{H}$ NMR $\left(500.10 \mathrm{MHz},\left[\mathrm{D}_{4}\right]\right.$ methanol, $\left.25^{\circ} \mathrm{C}\right): \delta=1.70(\mathrm{~s}, 15 \mathrm{H}$;

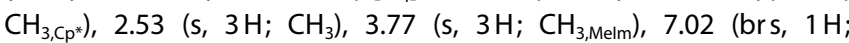
$\mathrm{CH}_{\text {Melm }}$ ), 7.17 (brs, $\left.1 \mathrm{H} ; \mathrm{CH}_{\text {Melm }}\right), 7.27\left(\mathrm{~d},{ }^{3} \mathrm{~J}(\mathrm{H}, \mathrm{H})=5 \mathrm{~Hz}, 1 \mathrm{H} ; \mathrm{CH}-5\right)$, $7.79 \mathrm{ppm} \quad$ (brs, 2H; $\mathrm{CH}_{\text {Melm }}$ \& $\left.\mathrm{CH}-6\right) ;{ }^{13} \mathrm{C} \mathrm{NMR} \quad(125.75 \mathrm{MHz}$, $\left[\mathrm{D}_{4}\right]$ methanol, $\left.\left.25^{\circ} \mathrm{C}\right): \delta=7.5\left(\mathrm{CH}_{3, \mathrm{Cp}}\right)\right), 13.7\left(\mathrm{CH}_{3}\right), 33.5\left(\mathrm{CH}_{3, \mathrm{Melm}}\right), 95.3$ $\left(\mathrm{d}, \quad{ }^{1} \mathrm{~J}(\mathrm{Rh}, \mathrm{C})=10 \mathrm{~Hz} ; \mathrm{C}_{\mathrm{Cp}^{*}}\right), \quad 120.5(\mathrm{CH}-5), 122.1 \quad\left(\mathrm{CH}_{\mathrm{Melm}}\right), 123.1$ $\left(\mathrm{CH}_{\text {Melm }}\right), 129.1\left(\mathrm{CH}_{\text {Melm }}\right), 146.7(\mathrm{CH}-6), 154.8\left(\mathrm{C}_{\mathrm{q}}-2\right), 164.8\left(\mathrm{C}_{\mathrm{q}}-3\right)$, $179.3 \mathrm{ppm} \quad\left(\mathrm{C}_{\mathrm{q}}-4\right)$; elemental analysis calcd (\%) for $\mathrm{C}_{20} \mathrm{H}_{26} \mathrm{~F}_{6} \mathrm{~N}_{2} \mathrm{O}_{2}$ PRhS: C 39.62, H 4.32, N 4.62, S 5.29; found: C 39.66, H $4.33, \mathrm{~N} 4.56, \mathrm{~S} 5.30$.

[(1-Methylimidazole- $\left.\kappa N^{3}\right)$ (2-methyl-3-(oxo- $\left.\mathrm{O} O\right)$-pyran-4(1H)-thionato- $\kappa S)\left(\eta^{5}-1,2,3,4,5\right.$-pentamethylcyclopentadienyl)iridium(III)] hexafluorophosphate (2d): The reaction was performed according to the general procedure for the synthesis of metal complexes with 1-methylimidazole as leaving group, using ligand L1 (42 mg, $0.296 \mathrm{mmol}$, 1 equiv), sodium methoxide $(18 \mathrm{mg}, 0.326 \mathrm{mmol}$, 1.1 equiv), and $\left[\left(\eta^{6}-\mathrm{Cp}^{*}\right) \mathrm{Ir}^{\mathrm{III}}(\mathrm{Melm})_{2} \mathrm{Cl}\right] \mathrm{Cl} \quad(150 \mathrm{mg}, \quad 0.267 \mathrm{mmol}$, 0.9 equiv). The mixture was stirred at $40^{\circ} \mathrm{C}$ for $4 \mathrm{~h}$, affording the desired product after work-up as orange-brown crystals. Yield: $61 \mathrm{mg}(32 \%) .{ }^{1} \mathrm{H}$ NMR $\left(500.10 \mathrm{MHz},\left[\mathrm{D}_{4}\right]\right.$ methanol, $\left.25^{\circ} \mathrm{C}\right): \delta=1.72$

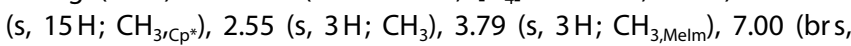
$\left.1 \mathrm{H} ; \mathrm{CH}_{\text {Melm }}\right), 7.15$ (brs, $\left.1 \mathrm{H} ; \mathrm{CH}_{\text {Melm }}\right), 7.31$ (brs, $\left.1 \mathrm{H} ; \mathrm{CH}-5\right), 7.78 \mathrm{ppm}$ (brs, $2 \mathrm{H} ; \mathrm{CH}_{\text {Melm }}$ \& $\left.\mathrm{CH}-6\right) ;{ }^{13} \mathrm{C}$ NMR $\left(125.75 \mathrm{MHz},\left[\mathrm{D}_{4}\right]\right.$ methanol, $\left.25^{\circ} \mathrm{C}\right): \delta=7.4\left(\mathrm{CH}_{3, \mathrm{Cp}^{*}}\right), 13.7\left(\mathrm{CH}_{3}\right), 33.4\left(\mathrm{CH}_{3, \mathrm{Melm}}\right), 87.7\left(\mathrm{~d},{ }^{1} \mathrm{~J}(\mathrm{Ir}, \mathrm{C})=\right.$ $\left.10 \mathrm{~Hz} ; \mathrm{C}_{\mathrm{Cp}^{*}}\right), 121.3(\mathrm{CH}-5), 122.0\left(\mathrm{CH}_{\mathrm{Melm}}\right), 123.3\left(\mathrm{CH}_{\mathrm{Melm}}\right), 129.4$ $\left(\mathrm{CH}_{\text {Melm }}\right), 146.1(\mathrm{CH}-6), 154.9\left(\mathrm{C}_{\mathrm{q}}-2\right), 165.8\left(\mathrm{C}_{\mathrm{q}}-3\right), 179.1 \mathrm{ppm}\left(\mathrm{C}_{\mathrm{q}}-4\right)$; elemental analysis calcd (\%) for $\mathrm{C}_{20} \mathrm{H}_{26} \mathrm{~F}_{6} \mathrm{IrN} \mathrm{N}_{2} \mathrm{O}_{2} \mathrm{PS}$ : C $34.53, \mathrm{H} 3.77, \mathrm{~N}$ 4.03, S 4.61; found: C 34.19, H 3.65, N 3.98, S 4.67.

\section{Single-crystal X-ray diffraction analysis}

X-ray intensity data were measured on a Bruker D8 Venture diffractor equipped with a multilayer monochromator, an $\mathrm{Mo}_{\mathrm{K \alpha}}$ INCOATEC microfocus sealed tube, and a Kryoflex II cooling device. Structures were solved by direct methods and refined by full-matrix leastsquares techniques. Non-hydrogen atoms were refined with anisotropic displacement parameters. Hydrogen atoms were inserted at calculated positions and refined with riding coordinates. The following software was used: frame integration, Bruker SAINT software package ${ }^{[44]}$ using a narrow-frame algorithm; absorption correction, SADABS; $;{ }^{[45]}$ structure solution, SHELXS-2013; $;{ }^{[46]}$ refinement, SHELXL-2013, ${ }^{[46]}$ OLEX2, ${ }^{[47]}$ and SHELXLE; ${ }^{[48]}$ molecular diagrams, OLEX2. ${ }^{[47]}$ CCDC1486550 (1 b), 1486549 (1 c), 1486552 (2 a), 1486554 (2 b), 1486551 (2 c), and 1486553 (2d) contain the supplementary crystallographic data for this paper. These data are provided free of charge by The Cambridge Crystallographic Data Centre. Experimental data, crystal data, data collection parameters, and structure refinement details are listed in the Supporting Information (Tables S1-S14). Molecular structures and packings are displayed in Figures S5-S8.

\section{ESI-MS measurements}

Electrospray ionization mass spectra were recorded on a Bruker AmaZon SL ion-trap mass spectrometer (Bruker Daltonics $\mathrm{GmbH}$ ). Data were acquired and processed using Compass 1.3 and Data Analysis 4.0 (Bruker Daltonics $\mathrm{GmbH}$ ). Mass spectra were recorded following direct infusion with a sample concentration of $5 \mu \mathrm{M}$ and a flow rate of $240 \mu \mathrm{Lh}^{-1}$. Small molecules were measured with the following settings: dry temperature: $180^{\circ} \mathrm{C}$, nebulizer: $8.00 \mathrm{psi}$, dry gas: $6.00 \mathrm{~L} \mathrm{~min}^{-1}$, and the high-voltage capillary was set to $-4500 \mathrm{~V}$ or $+4500 \mathrm{~V}$ for positive and negative mode, respectively. The target mass was set to $600 \mathrm{~m} / \mathrm{z}$. Samples for stability measurements and small molecule samples were diluted with water/methanol (50:50). Stock solutions of complexes $\mathbf{1} \mathbf{a}-\mathbf{d}$ and $\mathbf{2} \mathbf{a}-\mathbf{d}$ were prepared in DMSO and diluted to a final concentration of $1 \%$ in DMSO $/ \mathrm{H}_{2} \mathrm{O}$. The molar ratios used for interaction studies were complex:L-histidine:L-cysteine:glycine (1:1:1:1). Mass spectra were recorded after $0,1,3,6,24$, and $48 \mathrm{~h}$ of incubation at $37^{\circ} \mathrm{C}$.

\section{pH-Potentiometric titrations}

An Orion $710 \mathrm{~A} \mathrm{pH}$-meter equipped with a Metrohm combined electrode (type 6.0234.100) or Metrohm combined double-junction electrode (type 6.0255.100) and a Metrohm 665 Dosimat burette were used for the pH-potentiometric measurements. The exact concentrations of the ligand stock solutions together with the proton dissociation constants were determined by $\mathrm{pH}$-potentiometric titrations with the help of the computer program HYPERQUAD. ${ }^{[49]} \mathrm{RhCp}^{*}$ stock solutions were obtained by dissolving a known amount of $\left[\mathrm{RhCp}^{*}(\mu-\mathrm{Cl}) \mathrm{Cl}\right]_{2}$ in water. A stock solution of $\left[\mathrm{RhCp} *\left(\mathrm{H}_{2} \mathrm{O}\right)_{3}\right]\left(\mathrm{NO}_{3}\right)_{2}$ was obtained from an aqueous solution of $\left[\mathrm{RhCp}{ }^{*}(\mu-\mathrm{Cl}) \mathrm{Cl}\right]_{2}$ after removal of chloride ions using an equivalent amount of $\mathrm{AgNO}_{3}$. Concentrations of $\mathrm{RhCp}^{*}$ stock solutions were checked by $\mathrm{pH}$-potentiometric titrations employing stability constants for $\left[\left(\mathrm{RhCp}^{*}\right)_{2}\right.$ (hydroxido)] $\left(i=2\right.$ or 3 ) complexes. ${ }^{[22]}$ The $\mathrm{pH}-$ potentiometric measurements were carried out at $25.0 \pm 0.1{ }^{\circ} \mathrm{C}$ in water, and at an ionic strength of $0.20 \mathrm{M} \mathrm{KCl}$ or $\mathrm{KNO}_{3}$. Titrations were performed with carbonate-free $\mathrm{KOH}$ solution $(0.20 \mathrm{M})$. The exact concentrations of $\mathrm{HCl}, \mathrm{HNO}_{3}$, and $\mathrm{KOH}$ solutions were determined by $\mathrm{pH}$-potentiometric titrations. The electrode system was calibrated to the $\mathrm{pH}=-\log \left[\mathrm{H}^{+}\right]$scale by means of blank titrations (strong acid vs. strong base: $\mathrm{HCl} / \mathrm{HNO}_{3}$ vs. $\mathrm{KOH}$ ), as suggested by 
Irving et al. ${ }^{[50]}$ The average water ionization constant, $\mathrm{p} K_{\mathrm{w}}$, was determined as $13.76 \pm 0.01$ at $25.0^{\circ} \mathrm{C}, \mathrm{I}=0.20 \mathrm{M}\left(\mathrm{KCl}, \mathrm{KNO}_{3}\right)$, which corresponds well to literature values. ${ }^{[51]}$ The reproducibility of the titration points included in the calculations was within $0.005 \mathrm{pH}$ units. The $\mathrm{pH}$-potentiometric titrations were performed in the $\mathrm{pH}$ range between 2.0 and 11.5. The initial volume of the samples was $10.0 \mathrm{~mL}$. The ligand concentration was $1.0 \mathrm{~mm}$ and was investigated at metal ion-to-ligand ratios of 1:1, 1:1.5, and 1:2. The accepted fitting between the measured and calculated titration data points regarding the volume of the titrant was $<10 \mu \mathrm{L}$. The software PSEQUAD $^{[52]}$ was utilized to calculate the stoichiometry of the complexes as well as their overall stability constants. $\beta\left(\mathrm{M}_{p} \mathrm{~L}_{q} \mathrm{H}_{r}\right)$ is defined in Equation (1) for the general equilibrium:

$p \mathrm{M}+q \mathrm{~L}+r \mathrm{H} \rightleftharpoons \mathrm{M}_{p} \mathrm{~L}_{q} \mathrm{H}_{r}$ as $\beta\left(\mathrm{M}_{p} \mathrm{~L}_{q} \mathrm{H}_{r}\right)=\left[\mathrm{M}_{p} \mathrm{~L}_{q} \mathrm{H}_{r}\right] /[\mathrm{M}]^{\mathrm{p}}[\mathrm{L}]^{\mathrm{q}}[\mathrm{H}]^{\mathrm{r}}(1)$

where $\mathrm{M}$ denotes the metal moiety $\mathrm{RhC} \mathrm{p}^{*}$ and $\mathrm{L}$ is the completely deprotonated ligand. Values of $\log \beta$ of various $\left[\left(\mathrm{RhCp}^{*}\right)_{2}\right.$ (hydroxido)] ( $i=2$ or 3 ) complexes were calculated on the basis of $\mathrm{pH}$-potentiometric titration data in the absence and presence of chloride ions, and were in good agreement with our previously published data. ${ }^{[22]}$

\section{UV/Vis spectrophotometric and ${ }^{1} \mathrm{H}$ NMR titrations}

A Hewlett Packard 8452A diode-array spectrophotometer was used to record UV/Vis spectra in the interval $200-800 \mathrm{~nm}$. The pathlength (I) was either 1 or $2 \mathrm{~cm}$. Titrations were performed with samples containing only thiomaltol $(48 \mu \mathrm{M}), \mathrm{RhCp}^{*}(48 \mu \mathrm{M})$, or a 1:1 molar ratio of $\mathrm{RhCp}^{*}$ and the ligand over the $\mathrm{pH}$ range 2.0 11.5 at an ionic strength of $0.20 \mathrm{M}\left(\mathrm{KCl}\right.$ or $\left.\mathrm{KNO}_{3}\right)$ and at $25.0 \pm$ $0.1^{\circ} \mathrm{C}$ under anaerobic conditions. Measurements were carried out in the absence and presence of chloride ions, whereas the $0.20 \mathrm{M}$ $\mathrm{KCl}$ or $\mathrm{KNO}_{3}$ was partially or completely replaced by $\mathrm{HCl}$ or $\mathrm{HNO}_{3}$, and $\mathrm{pH}$ values in the range $0.7-2.0$ were calculated from the content of strong acid in the solutions. UV/Vis spectra were recorded to investigate the dependence of the $\mathrm{H}_{2} \mathrm{O} / \mathrm{Cl}^{-}$exchange processes in the $\left[\mathrm{RhCp}^{*}(\mathrm{~L})\left(\mathrm{H}_{2} \mathrm{O}\right)\right]^{+}$complex at $\mathrm{pH} 3.1$ on the $\mathrm{Cl}^{-}$concentration $(0-0.64 \mathrm{M})$. Stability constants for the co-ligand exchange were calculated with the software PSEQUAD. ${ }^{[52]}{ }^{1} \mathrm{H}$ NMR studies were carried out on a Bruker Ultrashield 500 Plus instrument or on a $600 \mathrm{MHz}$ Bruker Avance III spectrometer equipped with a $5 \mathrm{~mm}$ cryo-TXI $\left({ }^{1} \mathrm{H},{ }^{13} \mathrm{C},{ }^{15} \mathrm{~N}\right)$ probe. All ${ }^{1} \mathrm{H}$ NMR spectra were recorded with the WATERGATE water suppression pulse scheme using DSS as an internal standard. Thiomaltol was dissolved in a $10 \%(\mathrm{v} / \mathrm{v})$ $\mathrm{D}_{2} \mathrm{O} / \mathrm{H}_{2} \mathrm{O}$ mixture to yield a concentration of 1 or $0.1 \mathrm{~mm}$, and each solution was titrated at $25^{\circ} \mathrm{C}$, at I $=0.20 \mathrm{M}\left(\mathrm{KCl}\right.$ or $\left.\mathrm{KNO}_{3}\right)$, in the absence or presence of $\mathrm{RhCp}^{*}$ at a 1:1 metal-to-ligand ratio. Samples containing $\mathrm{RhCp}^{*}$ and thiomaltol at various ratios (1:1-1:5) at constant concentration of the ligand $(1 \mathrm{~mm})$ at $\mathrm{pH} 3.85(\mathrm{I}=0.2 \mathrm{M} \mathrm{KCl})$ and $2.70\left(\mathrm{I}=0.2 \mathrm{M} \quad \mathrm{KNO}_{3}\right)$ were measured. Stability $(\log K)$ and proton dissociation $\left(\mathrm{p} K_{\mathrm{a}}\right)$ constants for the complex $\left[\mathrm{ML}_{2} \mathrm{H}\right]$ were calculated using the software PSEQUAD. ${ }^{[52]}$

\section{Stability measurements under $\mathrm{pH}$ variation}

An Eco Scan $\mathrm{pH} 6 \mathrm{pH}$ meter equipped with a glass-micro combination $\mathrm{pH}$ electrode (Orion 9826 BN) was used. It was calibrated with standard buffer solutions of $\mathrm{pH} 4.00,7.00$, and 10.00. Complexes 2 a-d were dissolved in $\mathrm{D}_{2} \mathrm{O}(0.5 \mathrm{~mL})$ and $\mathrm{pD}$ values were determined instantly in the NMR tubes. The $\mathrm{pH}$ titrations were performed by addition of $\mathrm{NaOD}\left(0.4-0.0004 \%\right.$ in $\left.\mathrm{D}_{2} \mathrm{O}\right)$ and $\mathrm{DCl}(0.4-$ $0.0004 \%$ in $\mathrm{D}_{2} \mathrm{O}$ ). After each addition of either $\mathrm{DCl}$ or $\mathrm{NaOD}$, the samples were directly measured at $25^{\circ} \mathrm{C}$ using a Bruker Avance III ${ }^{\mathrm{TM}}$ $500 \mathrm{MHz}$ FT-NMR spectrometer. The experimentally obtained pD values were corrected according to Equation (2 ${ }^{[53]}$ in order to convert the measured values to the corresponding $\mathrm{pH}$ values in aqueous solution.

$$
\mathrm{pH}=0.936 \mathrm{pH}^{*}-0.412
$$

\section{Cell lines and culture conditions}

$\mathrm{CH} 1 / \mathrm{PA}-1$ cells (identified by STR profiling as PA- 1 ovarian teratocarcinoma cells by Multiplexion, Heidelberg, Germany) were obtained from Lloyd R. Kelland, CRC Centre for Cancer Therapeutics, Institute of Cancer Research, Sutton, UK. SW480 (human adenocarcinoma of the colon) and A549 (human non-small cell lung cancer) cells were kindly provided by Brigitte Marian (Institute of Cancer Research, Department of Medicine I, Medical University of Vienna, Austria). All cell culture media and reagents were purchased from Sigma-Aldrich Austria and plastic ware from Starlab Germany. Cells were grown in $75 \mathrm{~cm}^{2}$ culture flasks as adherent monolayer cultures in Minimum Essential Medium (MEM) supplemented with $10 \%$ heat-inactivated fetal calf serum, $1 \mathrm{~mm}$ sodium pyruvate, $4 \mathrm{~mm}$ L-glutamine, and $1 \%$ non-essential amino acids (from $100 \times$ ready-to-use stock). Cultures were maintained at $37^{\circ} \mathrm{C}$ in humidified atmosphere composed of $95 \%$ air and $5 \% \mathrm{CO}_{2}$.

\section{Cytotoxicity assay}

Cytotoxic effects of the tested compounds were determined by means of a colorimetric microculture assay [MTT assay; MTT $=3-$ (4,5-dimethyl-2-thiazolyl)-2,5-diphenyl-2H-tetrazolium bromide]. Cells were harvested from culture flasks by trypsinization and seeded at densities of $1 \times 10^{3}$ (CH1/PA-1), $2 \times 10^{3}$ (SW480), and $3 \times$ $10^{3}$ (A549) in $100 \mu \mathrm{L}$ per well aliquots in 96-well microculture plates. Before drug exposure, cells were allowed to settle and resume proliferation for $24 \mathrm{~h}$. Test compounds were first dissolved in DMSO, diluted with complete culture medium, and added to the plates, whereby the final DMSO content did not exceed $0.5 \%$. After $96 \mathrm{~h}$ of exposure, the medium was removed and replaced with $100 \mu \mathrm{L} /$ well of a 1:7 MTT/RPMI 1640 solution (MTT solution, $5 \mathrm{mg} \mathrm{mL}^{-1}$ of MTT reagent in phosphate-buffered saline; RPMI 1640 medium, supplemented with $10 \%$ heat-inactivated fetal calf serum (FCS), and $4 \mathrm{~mm}$ L-glutamine) and incubated for $4 \mathrm{~h}$ at $37^{\circ} \mathrm{C}$. Subsequently, the MTT/RPMI 1640 solution was removed from all wells, and the formazan crystals formed by viable cells were dissolved in $150 \mu \mathrm{L}$ of DMSO per well. Optical densities at $550 \mathrm{~nm}$ were measured with a microplate reader (Biotek $\mathrm{EL} \times 808$ ), using a reference wavelength of $690 \mathrm{~nm}$ to correct for nonspecific absorption. The quantity of viable cells was expressed in terms of $\mathrm{T} / \mathrm{C}$ values (relative to untreated controls), and $50 \%$ inhibitory concentrations $\left(\mathrm{IC}_{50}\right)$ were calculated from concentration-effect curves by interpolation. Evaluation was based on mean values from three independent experiments.

\section{Topoisomerase Il $\alpha$ inhibition}

The topoisomerase Il $\alpha$ inhibitory capacities of the tested compounds were determined by means of a DNA plasmid relaxation assay. For this purpose, we used a topoisomerase drug screening kit and human recombinant topoisomerase Il $\alpha$ enzyme from TopoGen Inc. The supercoiled pHOT1 plasmid DNA was incubated for $30 \mathrm{~min}$ at $37^{\circ} \mathrm{C}$ with topo Il $\alpha$ in the presence of various concentrations of the test compounds. Etoposide (VP-16) was used as a posi- 
tive control at a concentration of $0.8 \mathrm{~mm}$. The reaction was stopped by the rapid addition of $10 \%$ SDS followed by digestion with proteinase $\mathrm{K}$ for $15 \mathrm{~min}$ at $37^{\circ} \mathrm{C}$. The samples were divided and loaded onto two different $1 \%$ agarose gels with equal amounts of reaction products. One gel (Figures $6 \mathrm{~A}$ and $7 \mathrm{~A}$ ) was post-stained (after electrophoresis incubated in a $1 \times$ TAE buffer containing $0.7 \mu \mathrm{g} \mathrm{mL}^{-1}$ ethidium bromide) and the other gel (Figures $6 \mathrm{~B}$ and $7 \mathrm{~B})$ was pre-stained $\left(0.7 \mu \mathrm{g} \mathrm{mL}^{-1}\right.$ ethidium bromide added to the gel before electrophoresis). Both were analyzed by visualization with the detection system Fusion SL (Vilber Lourmat). Evaluation was based on two independent experiments.

\section{Cell cycle studies}

For this assay, SW480 cells were harvested by trypsinization and $1.2 \times 10^{5}$ cells were seeded into 12-well plates. In the first $24 \mathrm{~h}$, the cells were allowed to settle and resume proliferation. Thereafter, DMSO stock solutions of the tested compounds were diluted with MEM, and the medium in the plates was replaced with medium containing the test compounds so that the final DMSO content did not exceed $0.5 \%$. After continuous exposure for $12 \mathrm{~h}$ at $37^{\circ} \mathrm{C}$ and under $5 \% \mathrm{CO}_{2}$, the cells were trypsinized and centrifuged at $300 \mathrm{~g}$ for $3 \mathrm{~min}$. They were then washed with PBS $(1 \mathrm{~mL})$ and resuspended in $\mathrm{PI} / \mathrm{HSF}$ buffer $(600 \mu \mathrm{L} ; 0.1 \%$ Triton $\mathrm{X}-100,0.1 \%$ sodium citrate, in PBS) containing $50 \mu \mathrm{g} \mathrm{mL}^{-1}$ propidium iodide. After incubation overnight at $4{ }^{\circ} \mathrm{C}$ in the dark, $5 \times 10^{3}$ cells were measured by flow cytometry with a Millipore guava easyCyte $8 \mathrm{HT}$ instrument. Data were evaluated by means of FlowJo software (Tree Star) using Dean-Jett-Fox algorithms.

\section{Detection of intracellular reactive oxygen species}

DCF-DA ( $2^{\prime}, 7^{\prime}$-dichlorofluorescein diacetate) was used to detect the production of ROS. SW480 cells were seeded at densities of $2.5 \times$ $10^{4}$ cells in $100 \mu \mathrm{L} /$ well aliquots in 96-well microculture plates and were allowed to proliferate for $24 \mathrm{~h}$. The cells were washed with Hanks' balanced salt solution (HBSS) supplemented with $1 \% \mathrm{FCS}$, and were stained with $25 \mu \mathrm{M}$ DCF-DA for $40 \mathrm{~min}$ at $37^{\circ} \mathrm{C}$ under $5 \% \mathrm{CO}_{2}$. The cells were again washed with HBSS supplemented with $1 \% \mathrm{FCS}$, and complexes were added in phenol-red-free MEM supplemented with $1 \%$ FCS at the indicated concentrations. Fluorescence measurements were carried out with a Synergy HT microplate reader (BioTek Instruments) set to $37^{\circ} \mathrm{C}$. Measurements were performed with a $480 \mathrm{~nm}$ excitation and a $516 \mathrm{~nm}$ emission filter pair and a PMT sensitivity setting of 50 . Readings were conducted at intervals of $10 \mathrm{~min}$ for $120 \mathrm{~min}$. A $200 \mu \mathrm{M}$ solution of tert-butyl hydroperoxide (tbHP) was used as a positive control. Background (non-stained cells) was subtracted from all measurements, and fold change relative to the untreated control was determined.

\section{Acknowledgements}

The authors would like to thank the University of Vienna, the FWF Austrian Science Fund (project number P24659-N28), TÉT 15-1-2016-0024 bilateral research project, and the Hungarian Research Foundation OTKA project PD103905 for financial support.

Keywords: antitumor agents - leaving group variation medicinal chemistry $\cdot$ organometallics $\cdot$ thiomaltol
[1] P. Heffeter, U. Jungwirth, M. Jakupec, C. Hartinger, M. Galanski, L. Elbling, M. Micksche, B. Keppler, W. Berger, Drug Resist. Updates 2008, 11, $1-16$.

[2] L. S. Flocke, R. Trondl, M. A. Jakupec, B. K. Keppler, Invest. New Drugs 2016, 34, 261-268

[3] P. Heffeter, B. Atil, K. Kryeziu, D. Groza, G. Koellensperger, W. Körner, U. Jungwirth, T. Mohr, B. K. Keppler, W. Berger, Eur. J. Cancer 2013, 49, $3366-3375$.

[4] F. Frausin, V. Scarcia, M. Cocchietto, A. Furlani, B. Serli, E. Alessio, G. Sava, J. Pharmacol. Exp. Ther. 2004, 313, 227-233.

[5] A. Vacca, M. Bruno, A. Boccarelli, M. Coluccia, D. Ribatti, A. Bergamo, S. Garbisa, L. Sartor, G. Sava, Br. J. Cancer 2002, 86, 993-998.

[6] S. Leijen, S. A. Burgers, P. Baas, D. Pluim, M. Tibben, E. van Werkhoven, E. Alessio, G. Sava, J. H. Beijnen, J. H. M. Schellens, Invest. New Drugs 2015, 33, $201-214$.

[7] Y. K. Yan, M. Melchart, A. Habtemariam, P. J. Sadler, Chem. Commun. 2005, 4764-4776.

[8] W. H. Ang, A. Casini, G. Sava, P. J. Dyson, J. Organomet. Chem. 2011, 696 989-998.

[9] B. S. Murray, M. V. Babak, C. G. Hartinger, P. J. Dyson, Coord. Chem. Rev. 2016, 306, 86-114.

[10] R. Fernández, M. Melchart, A. Habtemariam, S. Parsons, P. J. Sadler, Chem. Eur. J. 2004, 10, 5173-5179.

[11] W. Kandioller, C. G. Hartinger, A. A. Nazarov, C. Bartel, M. Skocic, M. A. Jakupec, V. B. Arion, B. K. Keppler, Chem. Eur. J. 2009, 15, 12283-12291.

[12] W. Kandioller, C. G. Hartinger, A. A. Nazarov, M. L. Kuznetsov, R. O. John, C. Bartel, M. A. Jakupec, V. B. Arion, B. K. Keppler, Organometallics 2009, 28, 4249-4251.

[13] S. M. Meier, M. Hanif, W. Kandioller, B. K. Keppler, C. G. Hartinger, J. Inorg. Biochem. 2012, 108, $91-95$.

[14] I. F. Tannock, D. Rotin, Cancer Res. 1989, 49, 4373-4384.

[15] L. E. Gerweck, K. Seetharaman, Cancer Res. 1996, 56, 1194-1198.

[16] M. A. Bennett, A. K. Smith, J. Chem. Soc. Dalton Trans. 1974, 233-241.

[17] M. Hanif, H. Henke, S. M. Meier, S. Martic, M. Labib, W. Kandioller, M. A. Jakupec, V. B. Arion, H.-B. Kraatz, B. K. Keppler, Inorg. Chem. 2010, 49, $7953-7963$.

[18] M. Schmidlehner, P.-S. Kuhn, C. M. Hackl, A. Roller, W. Kandioller, B. K. Keppler, J. Organomet. Chem. 2014, 772-773, 93-99.

[19] A. F. A. Peacock, M. Melchart, R. J. Deeth, A. Habtemariam, S. Parsons, P. J. Sadler, Chem. Eur. J. 2007, 13, $2601-2613$.

[20] C. A. Vock, C. Scolaro, A. D. Phillips, R. Scopelliti, G. Sava, P. J. Dyson, J. Med. Chem. 2006, 49, 5552-5561.

[21] R. E. Morris, R. E. Aird, P. del Socorro Murdoch, H. Chen, J. Cummings, N. D. Hughes, S. Parsons, A. Parkin, G. Boyd, D. I. Jodrell, J. Med. Chem. 2001, 44, 3616-3621.

[22] O. Dömötör, S. Aicher, M. Schmidlehner, M. S. Novak, A. Roller, M. A. Jakupec, W. Kandioller, C. G. Hartinger, B. K. Keppler, É. A. Enyedy, J. Inorg. Biochem. 2014, 134, 57-65.

[23] É. A. Enyedy, É. Sija, T. Jakusch, C. G. Hartinger, W. Kandioller, B. K. Keppler, T. Kiss, J. Inorg. Biochem. 2013, 127, 161-168.

[24] M. Gras, B. Therrien, G. Süss-Fink, P. Štěpnička, A. K. Renfrew, P. J. Dyson, J. Organomet. Chem. 2008, 693, 3419-3424.

[25] É. A. Enyedy, O. Dömötör, C. M. Hackl, A. Roller, M. S. Novak, M. A. Jakupec, B. K. Keppler, W. Kandioller, J. Coord. Chem. 2015, 68, 1583-1601.

[26] É. A. Enyedy, J. P. Mészáros, O. Dömötör, C. M. Hackl, A. Roller, B. K. Keppler, W. Kandioller, J. Inorg. Biochem. 2015, 152, 93-103.

[27] J. L. Wike-Hooley, J. Haveman, H. S. Reinhold, Radiother. Oncol. 1984, 2 $343-366$.

[28] V. Pichler, S. Göschl, S. M. Meier, A. Roller, M. A. Jakupec, M. Galanski, B. K. Keppler, Inorg. Chem. 2013, 52, 8151-8162.

[29] A. Kanzaki, Y. Takebayashi, X.-Q. Ren, H. Miyashita, S. Mori, S. Akiyama, Y. Pommier, Mol. Cancer Ther. 2002, 1, 1327-1334.

[30] H. M. Leitner, R. Kachadourian, B. J. Day, Biochem. Pharmacol. 2007, 74, $1677-1685$.

[31] W. Berger, L. Elbling, E. Hauptmann, M. Micksche, Int. J. Cancer 1997, 73, 84-93.

[32] W. Berger, L. Elbling, M. Micksche, Int. J. Cancer 2000, 88, 293-300.

[33] V. Pichler, S. M. Valiahdi, M. A. Jakupec, V. B. Arion, M. Galanski, B. K. Keppler, Dalton Trans. 2011, 40, 8187-8192.

[34] P.-S. Kuhn, V. Pichler, A. Roller, M. Hejl, M. A. Jakupec, W. Kandioller, B. K. Keppler, Dalton Trans. 2015, 44, 659-668. 
[35] J. M. Fortune, N. Osheroff, J. Biol. Chem. 1998, 273, 17643-17650.

[36] J. L. Nitiss, Nat. Rev. Cancer 2009, 9, 338-350.

[37] N. Osheroff, Biochim. Biophys. Acta 1998, 1400, 1-2.

[38] M. Schmidlehner, L. S. Flocke, A. Roller, M. Hejl, M. A. Jakupec, W. Kandioller, B. K. Keppler, Dalton Trans. 2015, 44, 724-733.

[39] S. Mokesch, M. S. Novak, A. Roller, M. A. Jakupec, W. Kandioller, B. K. Keppler, Organometallics 2015, 34, 848-857.

[40] J. J. Soldevila-Barreda, P. J. Sadler, Curr. Opin. Chem. Biol. 2015, 25, 172 183.

[41] S. J. Dougan, A. Habtemariam, S. E. McHale, S. Parsons, P. J. Sadler, Proc. Natl. Acad. Sci. USA 2008, 105, 11628-11633.

[42] B. L. Booth, R. N. Haszeldine, M. Hill, J. Chem. Soc. Inorg. Phys. Theor. 1969, 1299-1303.

[43] J. W. Kang, K. Moseley, P. M. Maitlis, J. Am. Chem. Soc. 1969, 91, 59705977.

[44] Bruker SAINT V8.32B Copyright $\odot$ 2005-2015 Bruker AXS.

[45] Bruker (2001). SADABS Vers. 2012/1. Bruker AXS Inc., Madison, Wisconsin, USA.
[46] G. Sheldrick, Acta Crystallogr. Sect. A 2008, 64, 112-122.

[47] O. V. Dolomanov, L. J. Bourhis, R. J. Gildea, J. A. K. Howard, H. Puschmann, J. Appl. Crystallogr. 2009, 42, 339-341.

[48] SHELXLE, G. Hübschle, J. Appl. Cryst. 2011, 44, 1281.

[49] P. Gans, A. Sabatini, A. Vacca, Talanta 1996, 43, 1739-1753.

[50] H. M. Irving, M. G. Miles, L. D. Pettit, Anal. Chim. Acta 1967, 38, 475488.

[51] SCQuery, The IUPAC Stability Constants Database, Academic Software (Version 5.5), RSC, 1993-2005.

[52] L. Zekany, I. Nagypal, in Comput. Methods Determ. Form. Constants (Ed.: D. J. Leggett), Springer, Boston, 1985, pp. $291-353$.

[53] A. Kréżel, W. Bal, J. Inorg. Biochem. 2004, 98, 161-166.

Received: July 5, 2016

Published online on m, 0000 


\section{FULL PAPER}

\section{Antitumor Agents}

C. M. Hackl, M. S. Legina, V. Pichler, M. Schmidlehner, A. Roller, O. Dömötör, E. A. Enyedy, M. A. Jakupec, W. Kandioller, ${ }^{*}$ B. K. Keppler

\section{$\square-\square$}

Thiomaltol-Based Organometallic Complexes with1-Methylimidazole as Leaving Group: Synthesis, Stability, and Biological Behavior
En garde! 1-Methylimidazole ligands in thiomaltol-derived organometallics protect the complexes from premature decomposition and are cleaved under acidic tumor conditions releasing the active drug (see graphic). 